\title{
9. Social convergence, development failures and industrial relations: The case of Portugal
}

\section{Pilar González and António Figueiredo}

\section{CONTEXTUALISING THE PORTUGUESE CASE}

\subsection{Economic and Social Convergence: A Sequential or an Integrated Process?}

Since joining the European Union (EU) in 1986, convergence has been a constant issue of public scrutiny and discussion in Portugal, and the main concern of political actors. Several factors contribute to the focus on economic convergence. Portugal joined the EU with very low per capita income in comparative terms and practically all the political discourse that helped to transform EU integration into a national consensus was dominated by two main arguments: on the one hand, the EU was an essential protection for a young democracy such as Portugal; on the other hand, growth and development were presented as the main prospective outcome of integration, mainly because of the magnitude of the EU's internal market and because integration meant becoming a part of a globally powerful economic block. Not surprisingly, economic convergence arose as the main focus of public monitoring of the results achieved by the integration process. More effective and faster convergence would be in line with expectations and prove that democracy can pay for itself.

The classic question of 'Convergence to what?' was overshadowed by the importance of being or not being in convergence mode. In terms of the EU average or the more developed EU countries - mainly those most familiar to Portuguese people because of emigration (such as France and Germany) - the question of whether Portugal is in convergence mode has clearly prevailed over the issue of the pace of such convergence. It must also be underlined that adhesion to the euro zone was a particularly significant milestone in terms of how Portuguese citizens assess convergence. The common currency radically changed the way in which people compare their situation with that of other EU citizens.

Aware that convergence is not unidimensional and that it needs to be discussed further, in this chapter we use indicators of convergence towards the mean of the EU28 whenever possible. For some of the indicators we also include a reference to the EU15. ${ }^{1}$ The mean reference is an abstraction, and its adequacy for assessing a country's convergence effort can be questioned. Other possible references could be used to analyse convergence comparatively with the better performing countries in the EU, that is, those with the highest per capita gross domestic product (GDP). 
Moving from economic convergence to social convergence is a complex operation. On one hand, the normative dimension of social convergence cannot be avoided, considering either a possible composite social indicator or the option of a battery of social indicators. On the other hand, the social convergence process cannot be understood in Portugal unless one takes into account the very slow and problematic process of building and consolidating a welfare state. In a previous paper (González and Figueiredo 2015) we demonstrated how the social state in Portugal is recent, context dependent, unbalanced, encompassing and vulnerable. The devastating effects of the interrelated crises that recently hit the Portuguese economy (financial crisis and slow recovery, sovereign debt crisis and bailout of the Portuguese economy) provided a clear but painful illustration of how vulnerable the welfare state is in Portugal (González and Figueiredo 2015; Eichenbaum et al. 2016; Rodrigues et al. 2016; Caldas 2017).

The necessary understanding of economic and social convergence as an integrated -not a sequential - process of institutional and political consolidation is, in our view, a consequence of the development gaps existing when the country joined the EU. The need to consolidate a sustained trajectory of reducing income-per-capita gaps has evolved together with the ambition of developing a modern welfare state clearly inspired by the European model. During the 42 years of democracy and since integration in the EU, it is possible to identify some sub-periods in which Portuguese citizens have been confronted with the difficulty of achieving these two goals simultaneously. This was the case in the foreign exchange crisis of the 1980s, which was tackled with the support of the International Monetary Fund (IMF), but mainly in the decade 2000-2010 and the following bailout agreement in 2011. This latter period and its associated difficulties provided the definitive demonstration of how difficult it is (and will be) to achieve a steady-state of converging economic growth while simultaneously keeping alive the hope of social convergence within the EU model.

The difficulty of achieving sustained economic convergence and the increasing evidence of the exhaustion of the growth model generated in the golden period that followed EU accession show that structural change of the Portuguese economy has been slower than expected. This has given rise to two important effects, with repercussions for the expected economic and social convergence. First, the interruption of convergence and the emergence of signs of divergence in terms of real income per capita undermine the generally disseminated expectations of social convergence; secondly, it is becoming clear that the structural changes needed to regain a sustained trajectory of economic convergence are not independent of the particular configuration that social convergence might come to assume. Issues such as a more effective combination of flexibility and security in the labour market, and the needed transition to a skills-based competitiveness model, bring new challenges regarding the also needed social protection of the unskilled (long-term) unemployed people illustrate the type of social interdependences we are referring to.

The Troika adjustment period (2011-14) was a time of intense debate and conflict concerning the interdependence of conditions for economic and social convergence. The painful adjustment programme imposed on the Portuguese economy within the framework of the bailout's conditionalities introduced the topic of structural reforms into the country's political debate. 'Structural reforms' are vague, at least in terms of the bailout adjustment documents put forward by the Organisation for Economic Co-operation and Development (OECD), the European Central Bank (ECB), the IMF and the European 
Commission. Looking at the many reports and analyses of the Portuguese economy produced by these institutions, structural reforms seem to be imagined as changes considered necessary to develop the Portuguese economy in the direction of a more pro-market and pro-business environment. Not surprisingly, the focus derived from this understanding of structural reforms has been on labour market reforms. ${ }^{2}$ Other examples of structural reforms mentioned in the Troika memorandum - such as state administration reform, combating rent-seeking (mainly the energy and telecommunications sectors) and the regional organisation of the public sector - have lagged well behind the focus on labour market changes. The concept of structural reforms as envisaged by the Troika institutions is thus less effective than it could be as these reforms are focused too much on labour market liberalisation (a pro-market view of structural reforms) and less on the structural changes required by the transition towards a higher stage of development. Without ignoring the need for, and the advantages of, creating pro-market institutions in the Portuguese economy, limiting structural reforms to labour market changes is in conflict with an open discussion of the strategic alternatives for the Portuguese economy in pursuit of a new competitiveness model. We cannot ignore that Portugal joined the EU in the middle of a development transition aimed at reducing the existing development gap with the EU. Limiting structural change to labour market reforms thus seems to be a very narrow vision of the changes that development convergence requires. Issues such as (1) upgrading the production specialisation profile, (2) improving the national innovation system and its organisation around firms' innovation needs, (3) promoting accountability, (4) disseminating a meritocratic culture in the public sector and (5) increasing overall productivity are crucial components of a broader understanding of structural reforms, better designated 'structural change', as already mentioned. To focus structural change mainly on labour market reforms, in addition to being limiting can also be read as a hidden way of imposing changes in the Portuguese social model, without submitting it to democratic scrutiny.

Despite the controversial nature of the structural reforms laid down in the Troika adjustment plan, it appears that the Portuguese public believe that economic and social convergence can hardly be understood as separate expectations. Particularly with regard to labour market policies and institutions, changes in the Portuguese situation depend on the answers given to a much broader discussion on the following question: within a monetary union, how different can labour market institutions be while still maintaining symmetry and stability (Vandenbroucke 2017)? This is a crucial debate also for industrial relations and social dialogue. Given that most social convergence demands and expectations are distribution related, a complementary debate emerges, as formalised by Vandenbroucke (2017, p. 392): 'Institutions that monitor competitiveness should be embedded in social dialogue and distributive concerns should be mainstreamed in the monitoring of competitiveness. Mainstreaming distributive concerns into competitiveness makes the "assignment" for national social partners complex and challenging.'

This debate is far from being closed, indeed is scarcely out in the open. The role of social cohesion in competitiveness-led policies, especially within the framework of EU cohesion policy, is not yet well established. Although Portugal is now in a period of economic and social recuperation, there is no political consensus on the role of social cohesion in the convergence process. Different political agents give different answers to the question: should social cohesion be understood as a simple criterion for assessing 
the costs of competitiveness and growth or should it to be integrated into the design of growth and competitiveness policies (inclusive growth)? ${ }^{3}$

As we aim to demonstrate, industrial relations and social dialogue in Portugal are not mainstreamed to enhance an integrated view of inclusive growth. A sustained approach to economic and social convergence would require that employers and union representatives develop a perspective on social dialogue enriched by a combined vision of competitiveness goals and social targets. However, the established tradition in Portugal of strong political influence over industrial relations and social dialogue is not a friendly environment for mainstreaming competitiveness and distributive concerns in combination.

\subsection{Diversity of Social Convergence Paths and Dimensions}

Portugal's development gap with the EU average and the most developed member states is clearly represented by GDP per capita. After hovering in the 2000s at around 80-83 per cent of the EU28 per capita GDP (purchasing power standard, PPS), the bailout adjustment crisis during 2011-14 generated a type of hysteresis effect on per capita GDP. ${ }^{4}$ For four successive years (2013-16) per capita GDP (PPS) stabilised at 77 per cent of the EU28 mean, much lower than observed before the sovereign debt crisis.

However, we know that social convergence dimensions should be considered together with real economic convergence needs. A number of dimensions of Portugal's poor social performance by EU standards should be underlined, given their importance for the generation of social convergence expectations:

- Portugal faces a structural difficulty in reducing the percentage of people at risk of poverty or social exclusion to values below 25 per cent. ${ }^{5}$ In periods of poor labour market performance this percentage tends to increase significantly.

- The level of long-term unemployment due to low qualifications and insufficient training of the low-skilled labour force is one of the main dimensions of social exclusion and the poverty trap.

- Despite of the progress observed in the recent past, the still high (compared with the EU28) early dropout rate and the magnitude of the not in education, employment, or training (NEET) phenomena in Portugal (10.6 per cent of 15-24-yearolds and 17.2 per cent of 20-24-year-olds in 2016 $)$ emerge as the main features of social exclusion among the young. ${ }^{7}$

- Underperformance of youth employment in terms of wages and job opportunities remains a bottleneck to the enhanced social integration of young people and explains (at least partially) the intensity of the migration of high skilled youngsters.

- Notwithstanding the significant increase in female participation in higher education, women are still strongly disadvantaged in terms of wages, access to top executive jobs and intensity of participation in STEM activities, ${ }^{8}$ generating significant gender imbalances as regards returns to higher education.

- The bailout adjustment crisis seems to have interrupted the reduction of inequality observed in the second half of the 2000s; in 2014, after the end of the bailout, the Gini coefficient of equivalised disposable income was the ninth highest in the EU28 (34.5 per cent), although the values of 2015 and 2016 (34 per cent and 32.7 per cent, 
respectively) seemed to recover to readjust the falling trajectory of the coefficient upwards (González and Figueiredo 2015; Rodrigues et al. 2016).

More recently, especially after the tragic forest fires in June and October 2017, a new perspective emerged in the country with regard to the regional dimension of social convergence. Regional per capita GDP and productivity disparities represent a structural dimension of regional organisation in Portugal. Regional data show that, in general, disparities between regions measured by traditional indicators, such as GDP per capita, tend to increase in periods of high economic growth and to fall in crisis periods. There is also evidence that regional disparities are higher when measured by economic and productivity indicators than when the analysis is focused on social and environmental indicators. Notwithstanding the huge improvements brought about by the Structural Funds in terms of social facilities and infrastructure in the interior and less populated regions, the combination of such phenomena as ageing, isolation, sparse human settlement, budgetary crisis effects on public services and lack of enterprise significantly increases the weakness and vulnerability of these regions. The forest fires, mainly concentrated in the central region, were a cruel demonstration of that vulnerability, as well as of the failure, of public services.

A new dimension to economic and social convergence must then be added. Not only must economic and social convergence be combined, but measures are needed to monitor convergence progress (or setbacks) throughout the country. For example, demography matters considerably. The most vulnerable inner and low-density regions can no longer count on their own demographic forces. Their only hope is to attract people from other regions (which will be a tough task owing to the low demographic base) or from the outside through international migration (although Portugal is not one of the main migration destinations by any means).

The range of dimensions in which social convergence expectations are built up shows how crucial it is to combine economic and social convergence. The challenge is even more complex if we take into account the multiple institutional forms that tackling development failures can assume.

\subsection{How Did the Portuguese Industrial Relations System Contribute to the Convergence Process?}

Portugal is a recent democracy, and this cannot be ignored when we analyse recent economic, social and political dynamics in the country. ${ }^{9}$ This dimension is also present in the industrial relations system and has to be considered when analysing its effects on social convergence. ${ }^{10}$

\subsubsection{Historical contextualisation of industrial relations in Portugal: agents and process}

The design of the Portuguese industrial relations system is marked by the legacy of the authoritarian regime that prevailed in Portugal until 1974 and the process of transition to democracy against a revolutionary background initiated in 1974.

Free unions and collective bargaining were introduced only after democratic change in 1974. The following features of the industrial relations system are due to the inheritance of the dictatorship: strong state interference and the importance of the General 
Confederation of the Portuguese Workers (Confederação Geral dos Trabalhadores Portugueses, CGTP) union as legitimate representative of workers in accordance with its historical creation as a resistance institution. Furthermore, the industrial relations system created in 1974 and in its aftermath emerged in a context of strong power imbalances in the labour market, highly favourable to workers. The labour law that emerged from this period was strongly protective of employment and collective agreements. Labour relations in this period were also very conflictual and distrust between employers and unions was generalised.

Thus, the normalisation of labour relations in the country commenced from a normative system that was very centralised in labour law, very dependent on state intervention and characterised by very adversarial relations.

The normalisation of democracy also entailed the introduction of pluralism in the trade union movement, which resulted in adversarial relations between the established and the new union confederations. Mistrust between trade unions in the different confederations still characterises Portuguese industrial relations. The struggle concerning a unitary versus a pluralistic union movement has also been much politicised. Union confederations have developed very close links to political parties, which means that the union agenda is often closely related to the agenda of certain political parties.

The need to increase labour market flexibility after the normalisation of Portuguese democracy gave birth to the introduction of (very flexible) temporary contracts similar to those in other EU countries. The coexistence of very rigid regulation of fixed-term contracts and very flexible regulation of temporary contracts generated a labour force segmentation that still characterises the Portuguese labour market. ${ }^{11}$

In the mid-1980s, the Standing Committee for Social Concertation ${ }^{12}$ was set up, its purpose to create a new channel for centralised social dialogue. It is a tripartite body with representatives of the government, the union confederations (initially only the UGT ${ }^{13}$ but since 1987 also the $\mathrm{CGTP}^{14}$ ) and the employers' confederations (initially three and currently four confederations, on a sectoral basis: manufacturing, trade, agriculture and tourism). The main purpose of this body was to promote social dialogue by agreeing social pacts on matters of interest for all the parties. Initially, in the 1980s and 1990s, social pacts were related mainly to income policy, but they evolved to encompass broader issues such as education and training, health and safety, social security and its reform, boosting collective bargaining and minimum wages. Centralised social dialogue has been particularly dynamic since the mid-2000s. There has been an increase in the number of social pacts agreed, including medium-term pacts, the scope of the topics under discussion and of agreements has been widened and the number of actors involved has increased. For example, the CGTP (which previously refused to sign agreements) has signed three agreements (two bipartite with the UGT and a tripartite agreement with all the other actors). We argue ${ }^{15}$ that this process has helped build up trust among the social partners, which had been disrupted by the crisis and the consequent bailout.

\subsubsection{Collective bargaining and the density of union and employer organisations}

The Portuguese industrial relations system is organised mainly at the sectoral level. In recent decades and after the revolutionary period, union density ${ }^{16}$ has declined sharply (Figure 9.1). As regards the EU, Portugal ranks in the middle of the distribution as low union density is the rule in the majority of member states (Figure 9.2). 


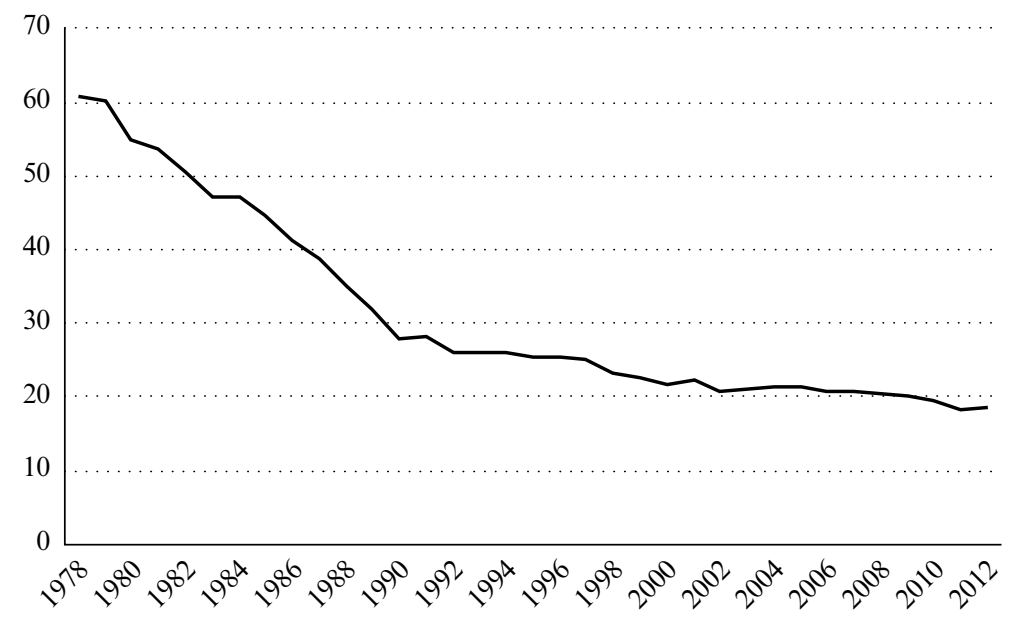

Note: Union density rate refers to net union membership as a proportion of wage earners in employment.

Source: Visser, available at ictwss_v5.1.

Figure 9.1 Union density in Portugal, 1978-2012

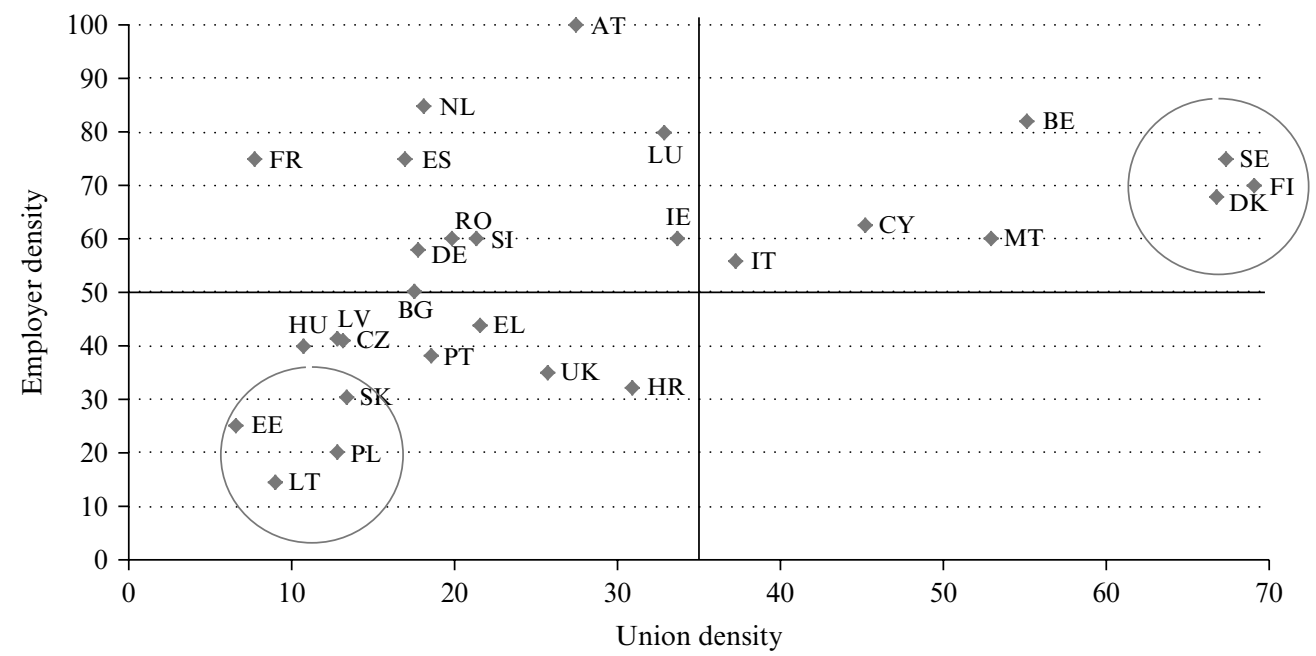

Notes:

(a) Union density rate: net union membership as a proportion of wage earners in employment.

(b) Employer organisation density: wage earners in firms organised in employers' organisations, as a proportion of employees in employment.

$* \quad$ Or the more recent available value.

Source: Visser, available at ictwss_v5.1.

Figure 9.2 Union (a) and employer organisation (b) density in Portugal and the EU, 2014* 
Figure 9.2 shows that diversity is the rule in the EU in terms of the representativeness of social partner organisations. The Nordic countries in particular have high density rates for both unions and employer organisations, while the central and eastern European countries have low values for both. This raises a number of important issues to be discussed at the national and EU levels:

- The importance of improving the representativeness of the social partners: a low organisational density can undermine legitimacy, which has to be prevented if industrial relations institutions and actors are to maintain their role in the design of labour market outcomes. Ultimately, this is also a question of improving democracy. In our view, social convergence is also needed in this domain at the European level.

- The difficulties of obtaining reliable and comparable information on the representativeness of the social actors hampers its effective evaluation. The statistical services at both EU and national levels have to be involved in the collection of such information.

- The full accomplishment of the European social model needs to be able to adapt the different industrial relations systems to new emerging realities in the labour market (new types of jobs, more qualified workers and a more diverse labour force). This can only be achieved with more transparency (more reliable information to support trust and dialogue) and more representation of both workers and firms.

- Low density at the national level can go together with high representativeness at the sectoral or firm level. ${ }^{17}$ Such knowledge is crucial, and very difficult to obtain from the available information, for an understanding of industrial relations dynamics and an adequate discussion of central issues such as centralisation versus decentralisation of collective bargaining. The extreme positions of 'ultra-liberal' economists, on the one hand, that collective action on the part of both workers (mainly) and employers (always) is 'bad' and that of 'uncritical institutionalists', on the other hand, that such collective action is almost always 'good' are, in methodological terms, equivalent. The quality of the institutions matters and the evaluation of this quality implies access to quantified information.

\subsubsection{Industrial relations and social convergence in Portugal}

Collective bargaining in Portugal operates mainly at the sectoral level. It is a complex system as several agreements can be negotiated in the same sector (involving different actors, professions and regions) and in the same firm. Collective agreements traditionally regulate wage-setting and working-time arrangements and thus have important potential effects on social convergence through their effects on poverty and inequality.

At the national level social dialogue has also been important in introducing some consensus (or at least the minimum possible agreement) on changes in the Labour Code and in minimum wage-setting, initiating dynamics (even if potentially contradictory) that influence income distribution:

- The minimum wage is an important means of reducing in-work poverty and wage inequality. However, we should be aware that, as has been the case in Portugal, increases in the minimum wage have not been accompanied by an identical dynamic 
along the wage distribution, leading to an increase in the share of workers paid at the minimum wage (in Portugal during the period 2013 to 2016 in the private sector this share increased from 12.0 to 23.3 per cent $^{18}$ ). Thus there has been an improvement of the situation of the very bottom wage-earners but alongside the trapping of an increasing amount of workers at that wage level. The necessary discussion of minimum wages should thus be expanded to a more general debate on low wages and the need to overcome them for the sake of both efficiency and fairness. The industrial relations dynamics fostered by proactive social dialogue may be seen as a first step to this broader discussion about the minimum wage.

- Evidence of the importance of social pacts in the social engagement of industrial relations actors can be provided by some statements in the final documents, as in the case for the 2006 minimum wage pact:

[Social partners consider that] the minimum wage is too low in Portugal and that its gradual increase is desirable, taking into account the economic reality of the country and that of other EU countries [and that] it is necessary to support the development of those sectors and firms with higher concentration of low wages and/or higher exposure to international competition, in order to promote their modernisation, allowing the creation of higher added value and higher wages. ${ }^{19}$

- There is explicit recognition of the low value of wages in Portugal (also by EU standards) and the need to increase them.

- Labour legislation has undergone important changes since 2003 in pursuit of improved labour flexibility. Despite the difficulties of this process negotiations have allowed some consensus to be built, giving rise to social pacts on important labour market issues. However, the period during which the Troika held sway interrupted this accumulation of trust among the social partners, as no real importance was attached to this dimension of social change. ${ }^{20}$ It is important to reintroduce this process, centred not only on the (needed) flexibility but also on the (also needed) security of workers. The negative effects of this interruption are key evidence of the importance of industrial relations.

- Changes in the regulation of industrial relations ${ }^{21}$ during the crisis concerned mainly the extension of collective agreements. In 2012,22 and unilaterally, the government defined very restrictive criteria for the extension of collective agreements to firms and workers not affiliated to the associations that negotiated them. This change was strongly opposed by both employers and workers' associations as they considered that this undermines collective bargaining. In the words of the leader of the largest employers' confederation this resolution 'undermines the possibility, in practice, of extending collective agreements and this in turn favours disloyal competition, disaggregates employers and removes incentives for their affiliation, fosters informal economic activity and seriously hurts collective bargaining. ${ }^{23}$ The unions' criticisms focused mainly on wage inequality that hits more vulnerable workers hardest. The government later (Resolution 43/2014) changed these criteria, making them much more extensive. 


\section{FROM ECONOMIC TO SOCIAL CONVERGENCE}

Portugal is a low per capita GDP country, ranking well below the EU average (Figure 9.3). There has been no sign of clear convergence since the end of the 1990s (Figure 9.4). The recent crisis brought about a strong divergence shock in this regard and there have been no signs of recovery.

Although revitalised after the end of the bailout adjustment, industrial relations and social dialogue in particular operate in a context in which GDP per capita still lags behind its pre-crisis values, showing that development failures cannot be forgotten.

Within this context of persistent economic divergence, how has social structure evolved? We shall organise the analysis around five main topics: the labour market, poverty and social inclusion, inequality, education and the industrial relations system.

\subsection{Labour Market: Influence of Social Dialogue and Social Partners}

The Portuguese labour market has long performed well in EU terms. Despite the prevailing low wages, until very recently low unemployment rates coexisted alongside high participation and employment rates (Figures 9.5 and 9.6).

\subsubsection{Participation, employment and unemployment}

The financial and economic crisis particularly disrupted the Portuguese labour market. Convergence with the EU unemployment rate (on course since the early 2000s) changed to an increasing divergence. Since 2014 unemployment and employment rates have begun to converge again towards the EU average. Whether this is mainly a rearrangement brought about by the crisis or a persistent change in the direction of Portuguese convergence (meaning, in this case, a negative change) towards EU employment and unemployment levels remains to be seen. Anyway, the increase in the unemployment rate since the early 2000 s signals more of a structural change than the sole effect of the crisis. The mismatch between supply and demand of skills and the difficulties of (re)training unskilled and older workers - who are highly represented in long-term unemployment are examples of such structural changes.

\subsubsection{Increasing duality?}

Labour market dynamics are also reflected in forms of employment. Figure 9.8 shows clearly that temporary contracts are particularly important in Portugal (compared with the EU average). Since the mid-1990s a duality between permanent and temporary workers has become one of the structural characteristics of the Portuguese economy (see Figure 9.7). This increasing duality indicates concrete demand for flexibility in labour contracts among firms, but the use of temporary contracts as a generalised instrument of such flexibility hinders convergence as it increases precarious employment. Also, we cannot say that the debate on temporary contracts has to date been a priority of social dialogue and it must urgently be included in the social dialogue agenda.

The share of part-time employment in the Portuguese labour market remains low for both male and female employees (Figures 9.9 and 9.10). Part-time employment as an instrument of adaptability is much less present in the Portuguese labour market than in other EU countries (Figure 9.11). 


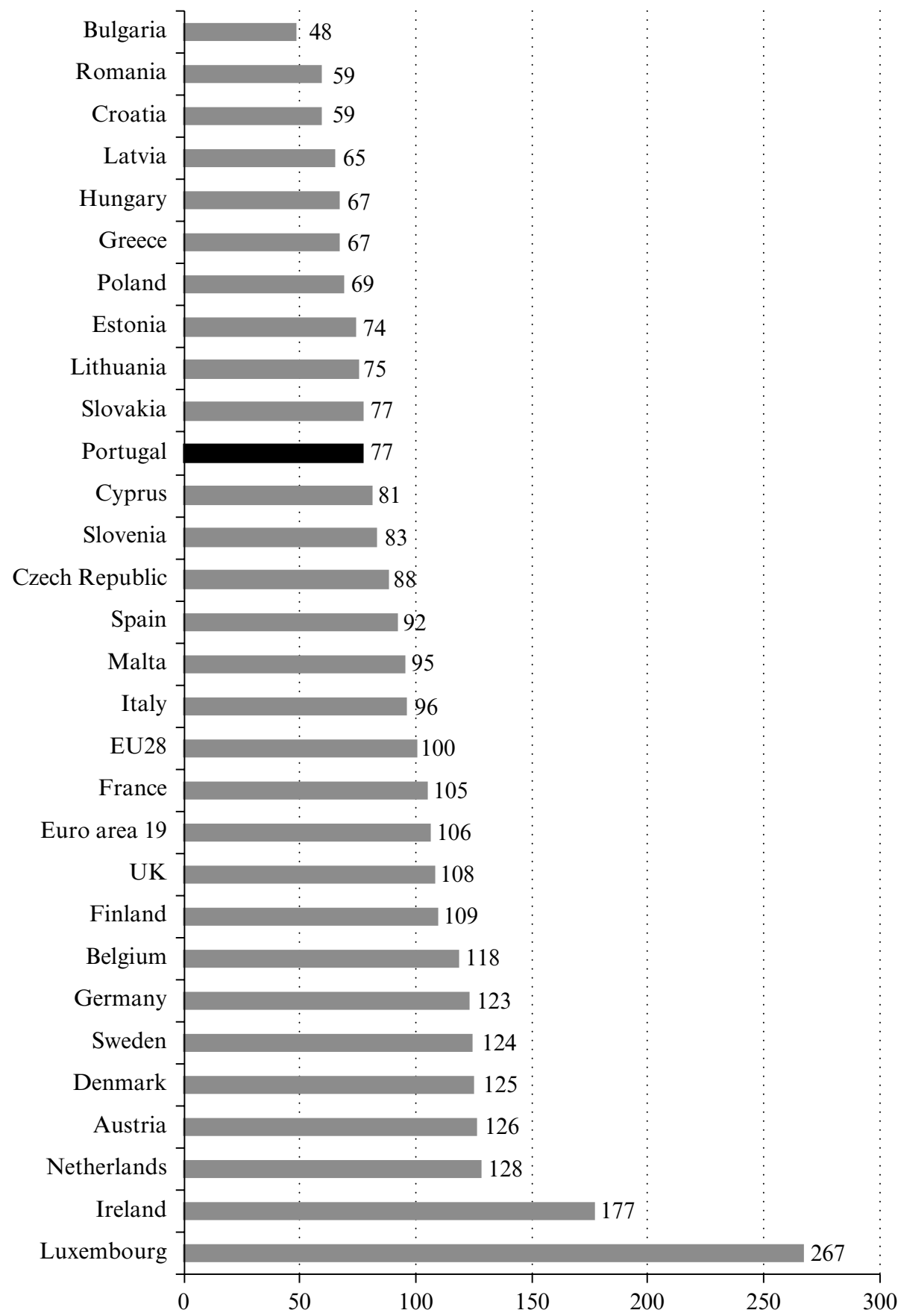

Source: Eurostat.

Figure 9.3 Per capita GDP in Portugal and the EU, 2016 (index: EU28 = 100) 


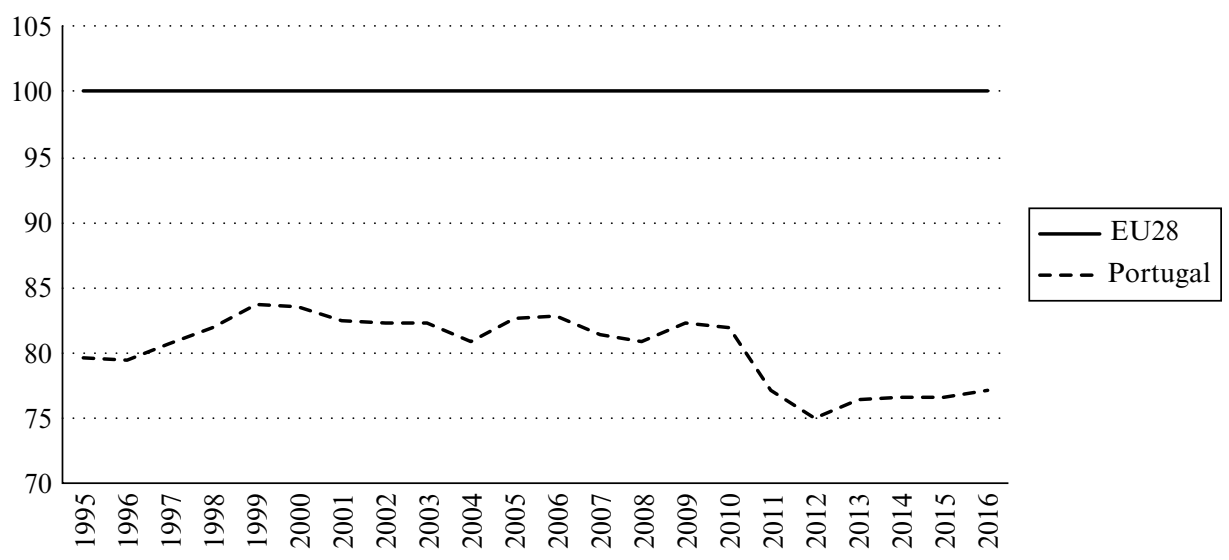

Source: Eurostat.

Figure 9.4 GDP per capita in PPS, EU28 and Portugal, 1995-2016 (index, EU28= 100)

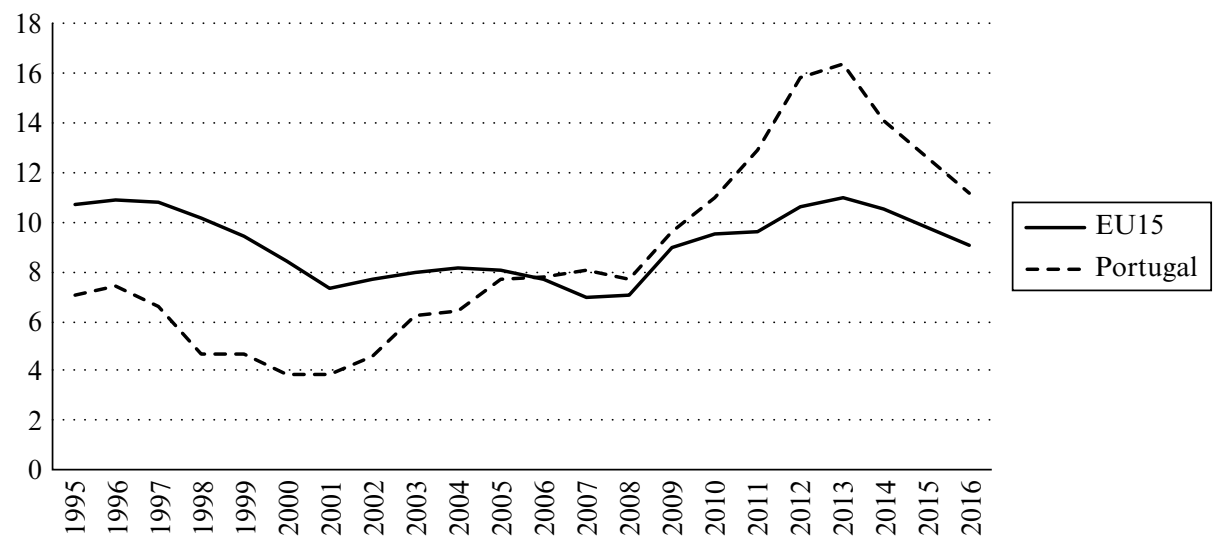

Source: Eurostat.

Figure 9.5 Unemployment rate, Portugal and EU15, 1995-2016

\subsubsection{Work-life balance}

The picture of gender diversity presented in Figure 9.11 is in line with the well-known female-biased incidence of part-time work. This leads us to consider the mechanisms of work-life balance and its shaping and evolution in Portugal and the EU.

Portugal has long been a country of high employment activity (currently similar to the EU15 level) and especially of high female activity (Figures 9.12 and 9.13).

Portuguese mothers do not reduce their employment rate much if they have more children (maternal employment rates of women with one and with two children were, respectively, 76.2 and 76.5 per cent; the rate falls to 63.8 per cent for three or more 


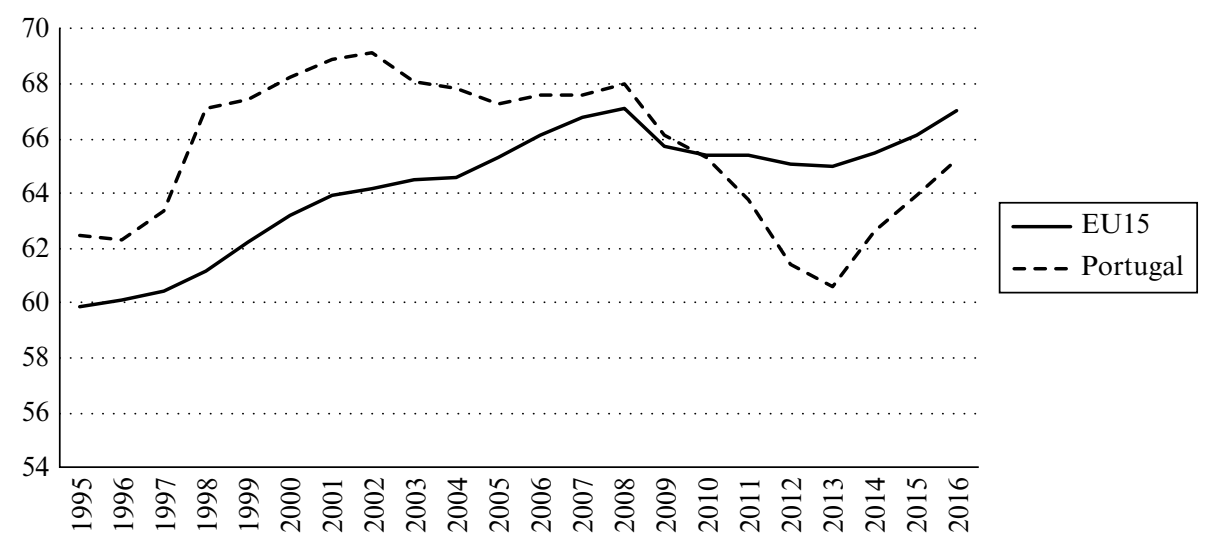

Source: Eurostat.

Figure 9.6 Employment rate, Portugal and EU15, 1995-2016

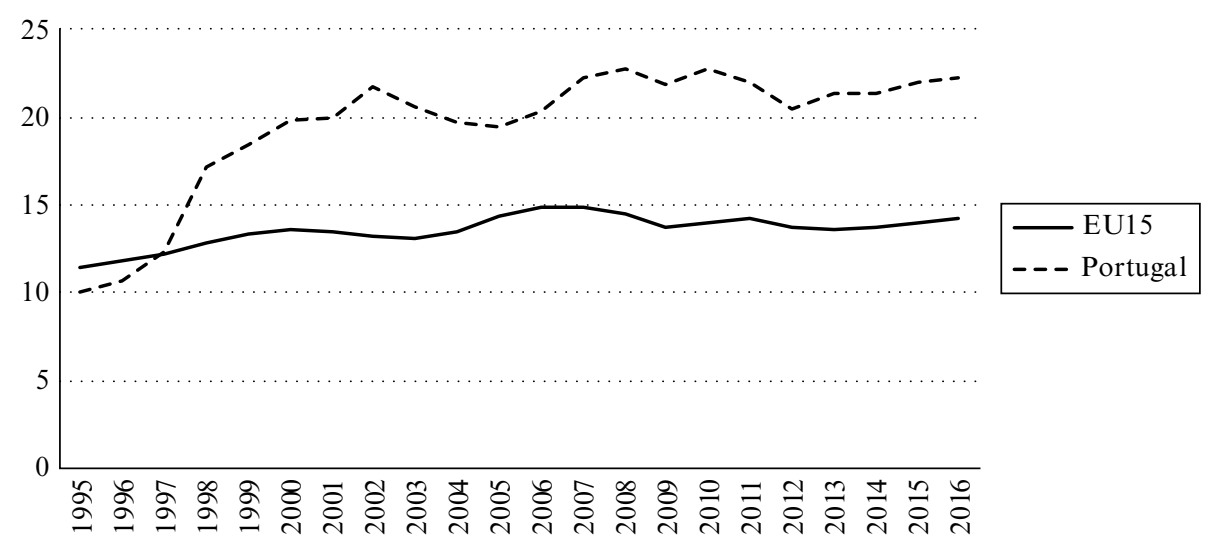

Source: Eurostat.

Figure 9.7 Share of temporary employees in total employment, Portugal and EU15, 1995-2016 (percentage)

children) or with the age of the children (the maternal employment rate is 73.2 per cent if the youngest child is aged $0-2$ years and 76.5 per cent for a youngest child aged 3-5 years). ${ }^{24}$ Data on the paternal employment rate are not available (probably because male activity is not expected to correspond to the age and number of children). Data on labour market status in terms of both paternity and maternity are very much needed because the size of the existing gaps and their evolution is important and because, in several member states, as in Portugal, compulsory paternity leave and its extension have been accorded high importance within family policies and their effects need to be duly evaluated. 


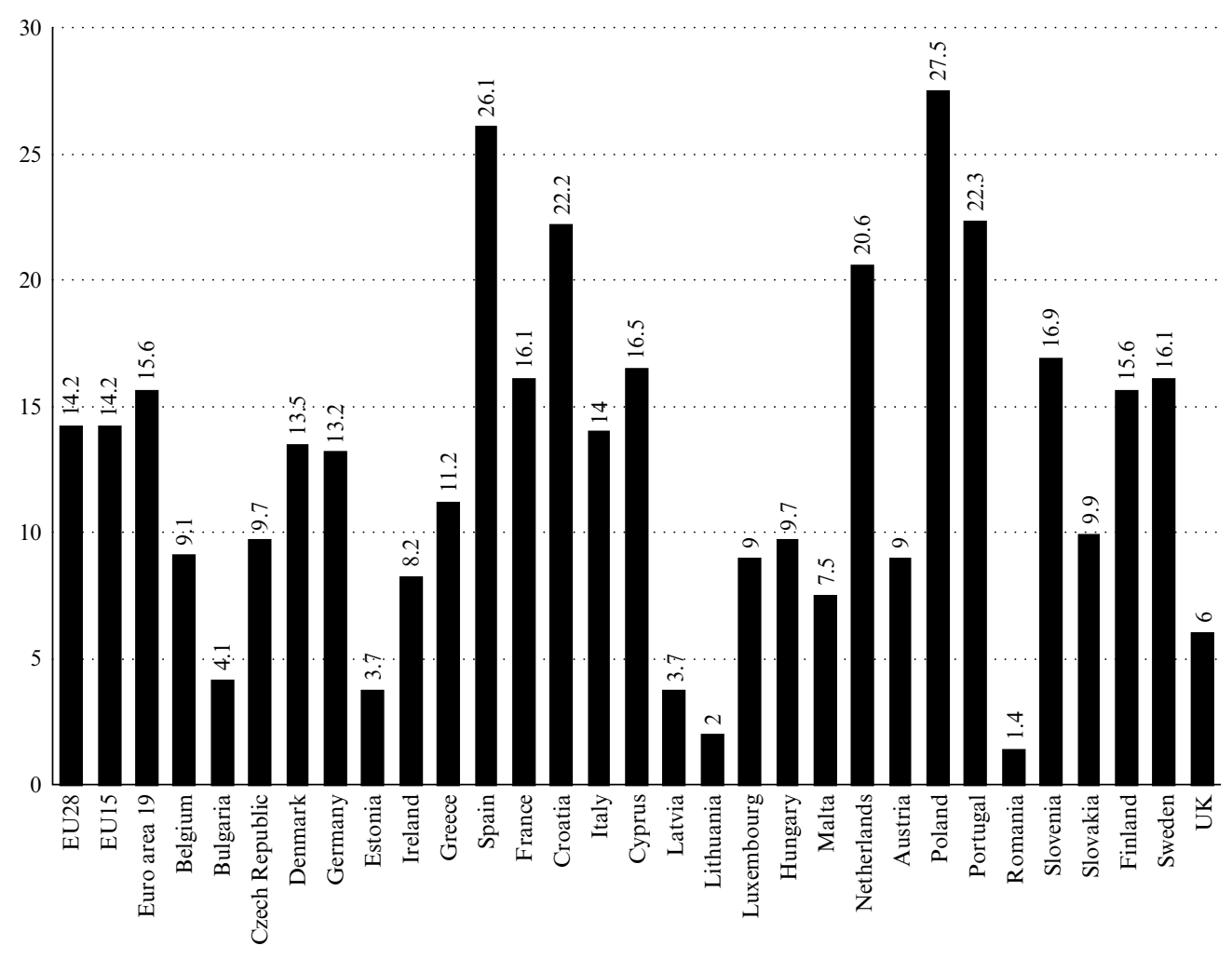

Source: Eurostat.

Figure 9.8 Share of temporary employees in total employment, Portugal, EU15, EU28 and member states

Given the low per capita GDP (and low wages - see below) in Portugal what are the main mechanisms for reconciling work and family life?

Public investment in childcare and the development of social infrastructure in this area have made it easier for families to access external care. ${ }^{25}$ Enrolment rates for 0-2-yearolds and 3-5-year-olds in pre-school and pre-primary education were, in 2014, 54.7 and 87.9 per cent, respectively, above the EU28 average. ${ }^{26}$

However, very low fertility rates also play a major role in how families adjust their childcare and labour market participation. While low fertility is a well-known (although not frequently discussed as an economic, social and political issue) problem facing both richer and poorer countries in the EU, it is particularly felt in southern European countries, with Portugal ranking at the very bottom (Figures 9.14 and 9.15). We think that demography should play a more central role in social and political debates and in social dialogue. For industrial relations the relevant topic is not the evolution of fertility in itself but rather work-life balance. Owing to the estimated negative rates of natural population growth, the challenge of generating a long-term sustained trajectory of fertility increase cannot rely on families alone. Social investment of firms in generating a friendlier work- 


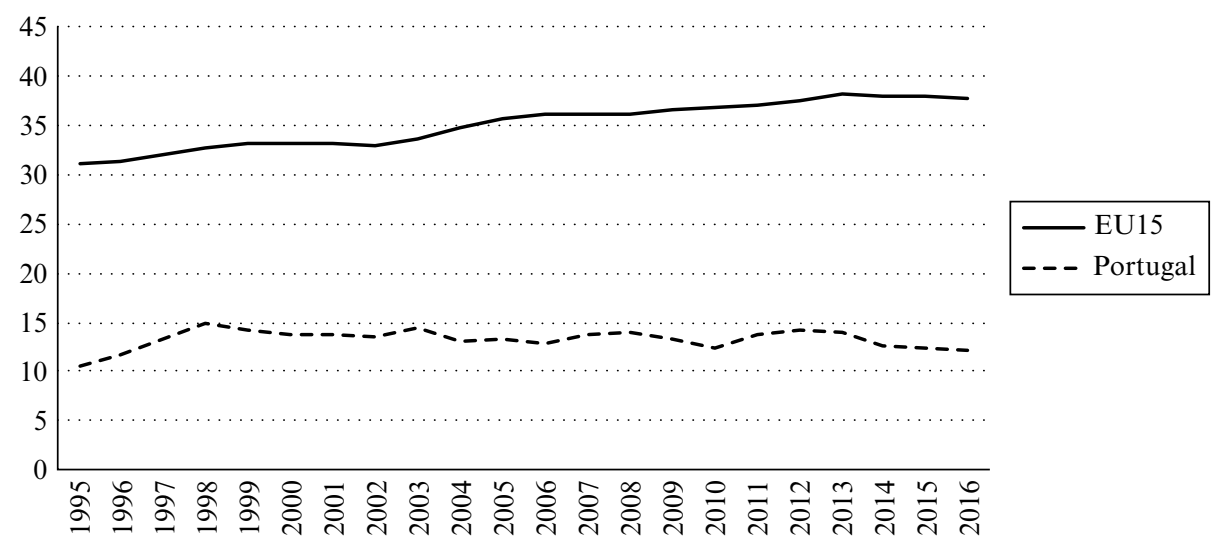

Source: Eurostat.

Figure 9.9 Share of part-time in total employment, women, Portugal and EU15, 1995-2016

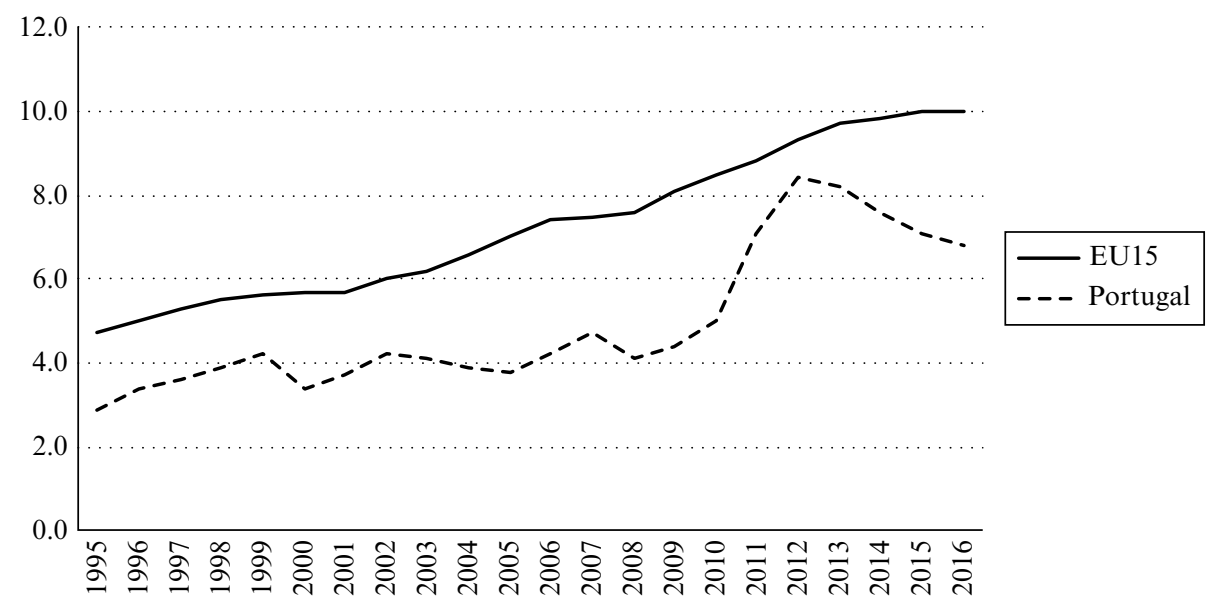

Source: Eurostat.

Figure 9.10 Share of part-time in total employment, men, Portugal and EU15, 1995-2016

life balance will be crucial and consequently a relevant issue for social dialogue. There is some evidence of the importance of negotiation on this issue. A tripartite agreement signed in 2008, which paved the way to the changes in the Labour Code in 2009, includes, as a counterpart of negotiating higher work flexibility, improvements in maternity and paternity leave support. ${ }^{27}$ 


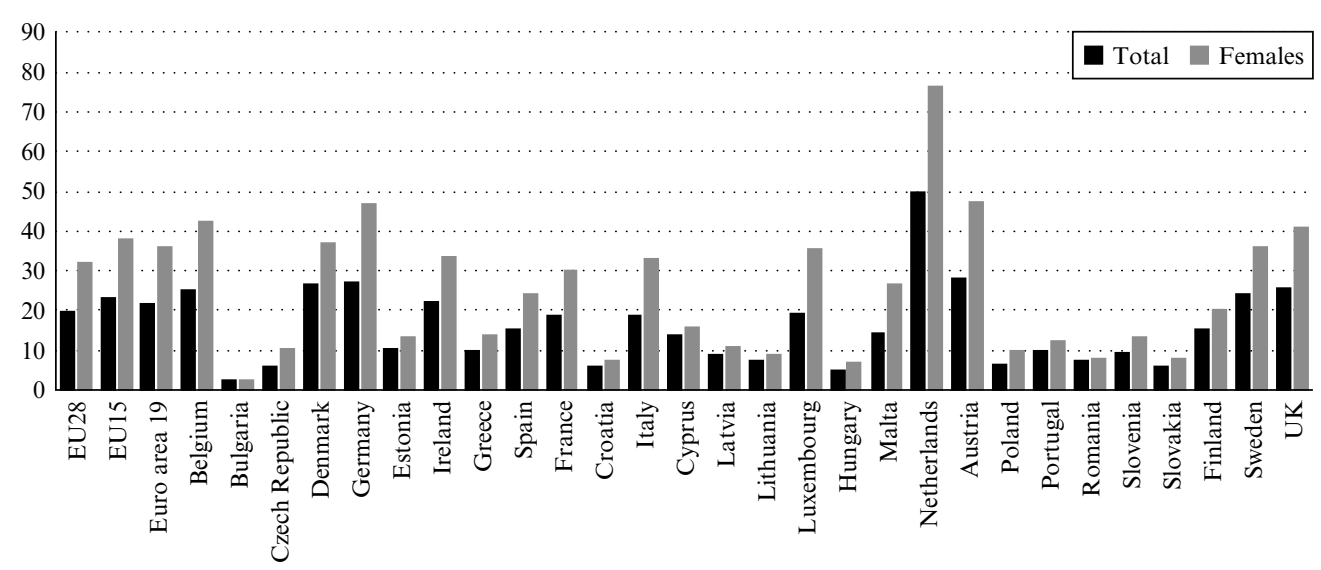

Source: Eurostat.

Figure 9.11 Share of part-time in total employment, Portugal, EU15, EU28 and member states, 2016

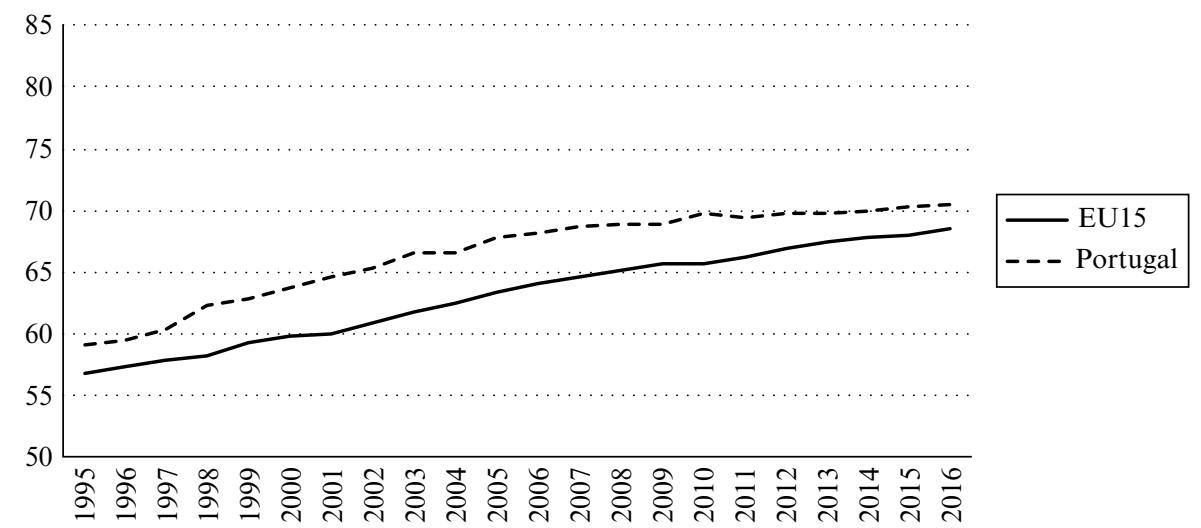

Source: Eurostat.

Figure 9.12 Activity rate, women, Portugal and EU15, 1995-2016

\subsubsection{Wage distribution and low pay}

Portuguese wages are very low by EU standards (Figure 9.16). A comparative assessment of wage development is often difficult due to the scarcity of comparable information across countries and over time. Using a proxy for wages in the different EU countries (total wages as a percentage of total population ${ }^{28}$ ) we can see no clear signs of convergence in the late 1990s and slow signs of divergence since the beginning of the 2000s, exacerbated since the beginning of the crisis (Figure 9.17). During the bailout adjustment, public sector employment was maintained in exchange for severe wage cuts. As for the private sector, jobs cuts and constant or even falling wages for those who kept 


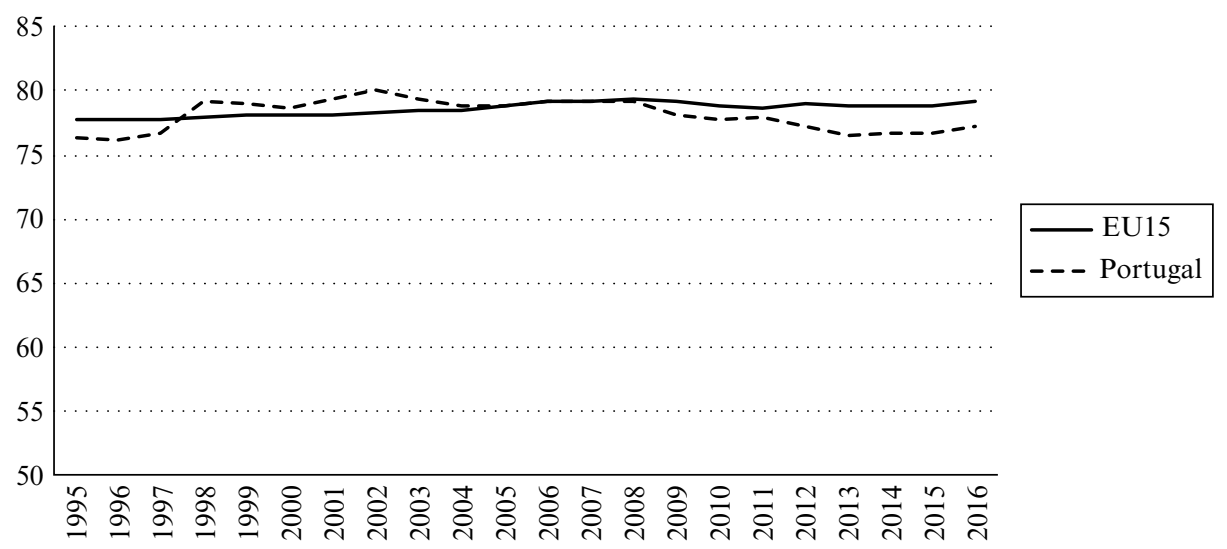

Source: Eurostat.

Figure 9.13 Activity rate, men, Portugal and EU15, 1995-2016

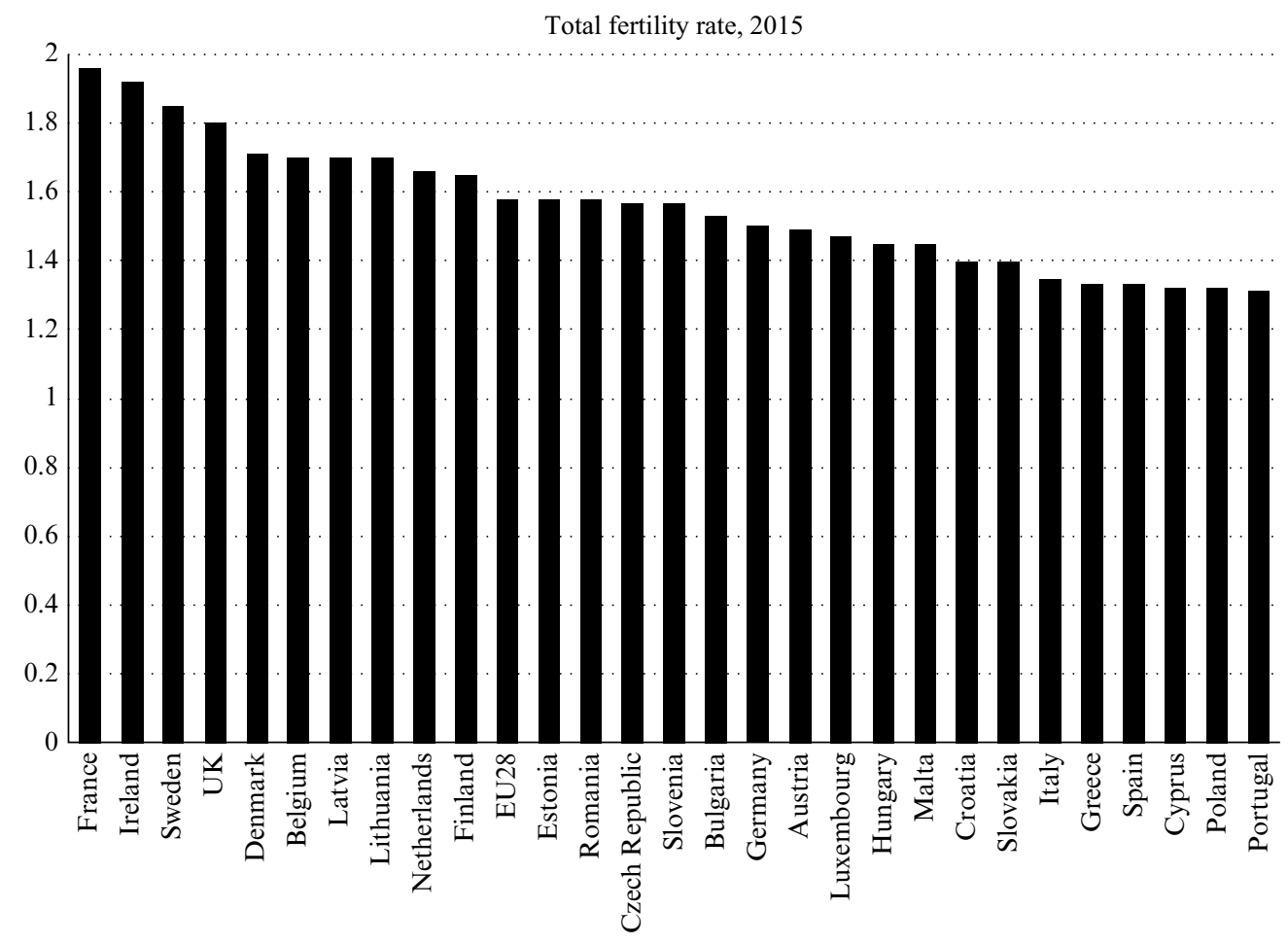

Source: Eurostat.

Figure 9.14 Total fertility rate, Portugal and EU member states, 2015 

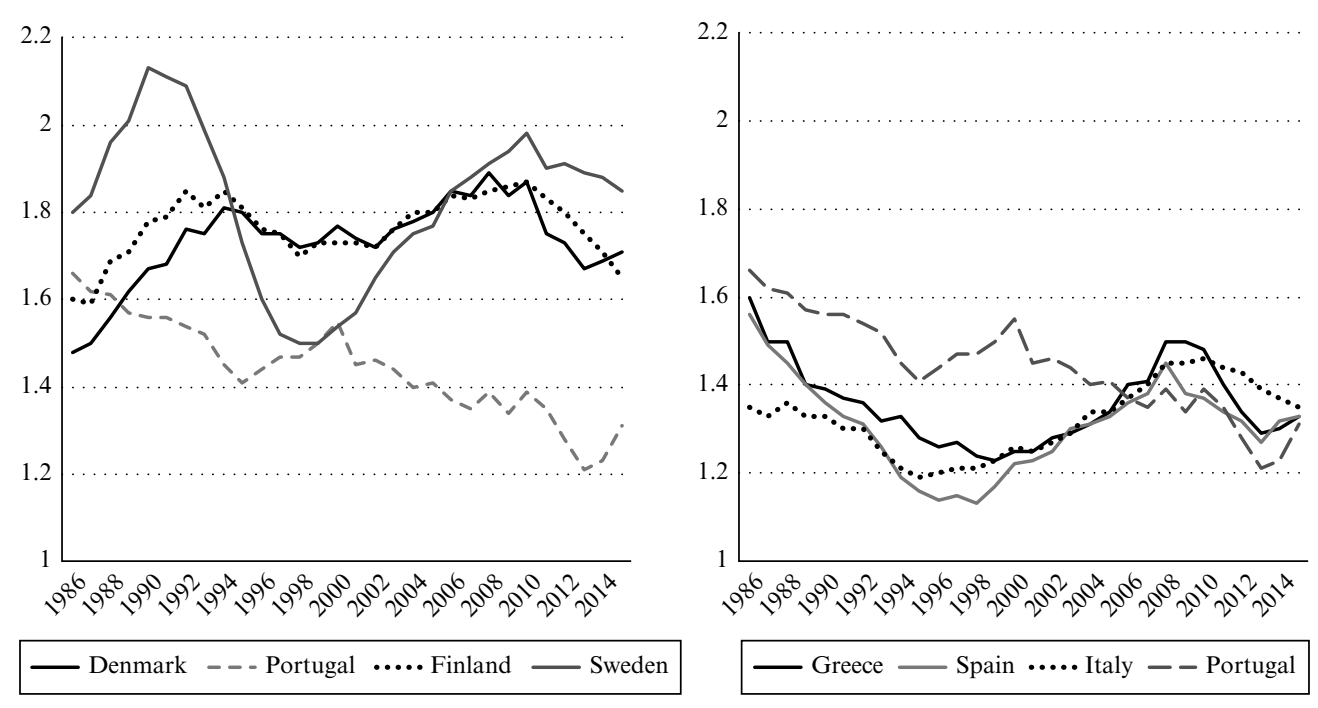

Source: Eurostat.

Figure 9.15 Total fertility rate in Portugal and selected EU member states, 1986-2014

their jobs are additional reasons for the fall in wages across the board. The downward evolution also reflects a dynamic of industrial relations in which the employers enhanced their relative position as the bailout adjustment period tended to unbalance employeremployee relations in favour of the former.

Minimum wages have had an important role in the evolution of wages. Their impact must be analysed from two standpoints: (1) minimum wages can push up other wages (Figure 9.18), but (2) if the ratio between the minimum and the average wage is high (Figure 9.19), they help to reduce inequality at the bottom of the wage distribution by increasing the share of minimum wage earners (Figure 9.20).

Upgrading the minimum wage in Portugal is an issue on which the social dialogue institutions have played an important role. In 2006 an important agreement was signed (see above) by all social partners on minimum wages. This agreement recognised the 'low value of the existing minimum wage in Portugal, as well as the desirability of its gradual increase' and the 'importance of defining the evolution of the monetary value of the minimum wage on a medium term basis in order to ensure both predictability and trust for firms and workers' (CES 2006, p. 1). This was a significant characteristic of the period before the crisis: increasing trust among the social partners was accumulated in the course of institutional social dialogue, compared with the conflictual pattern of the 1970s, the 1980s and most of the 1990s. This trust had a very positive effect on the functioning of the Portuguese labour market, creating very favourable (even if not permanent) social conditions until the crisis, while austerity policy has severely disrupted this favourable context. ${ }^{29}$ 


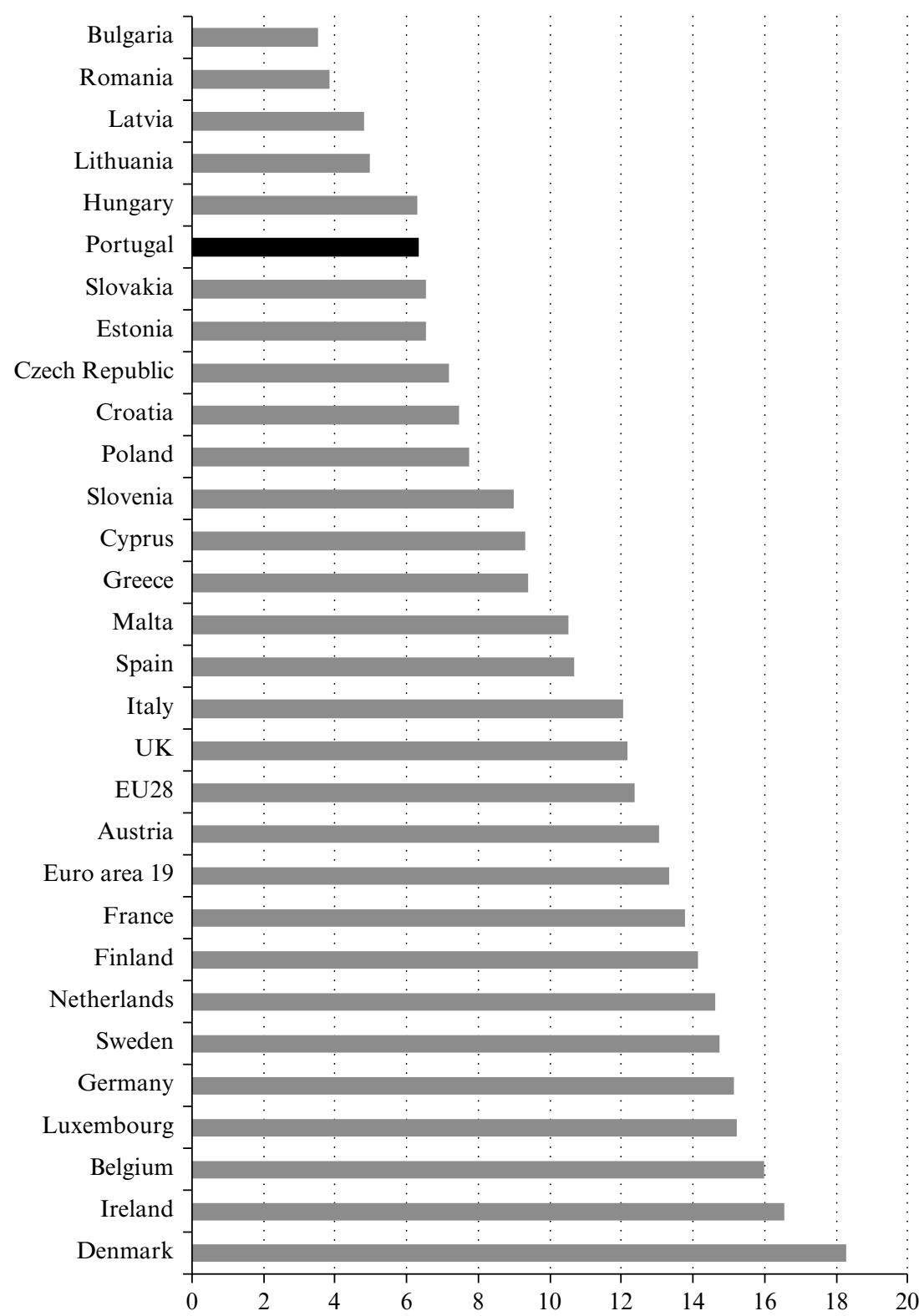

Source: Eurostat.

Figure 9.16 Median hourly earnings in PPS, Portugal and EU member states, 2014 


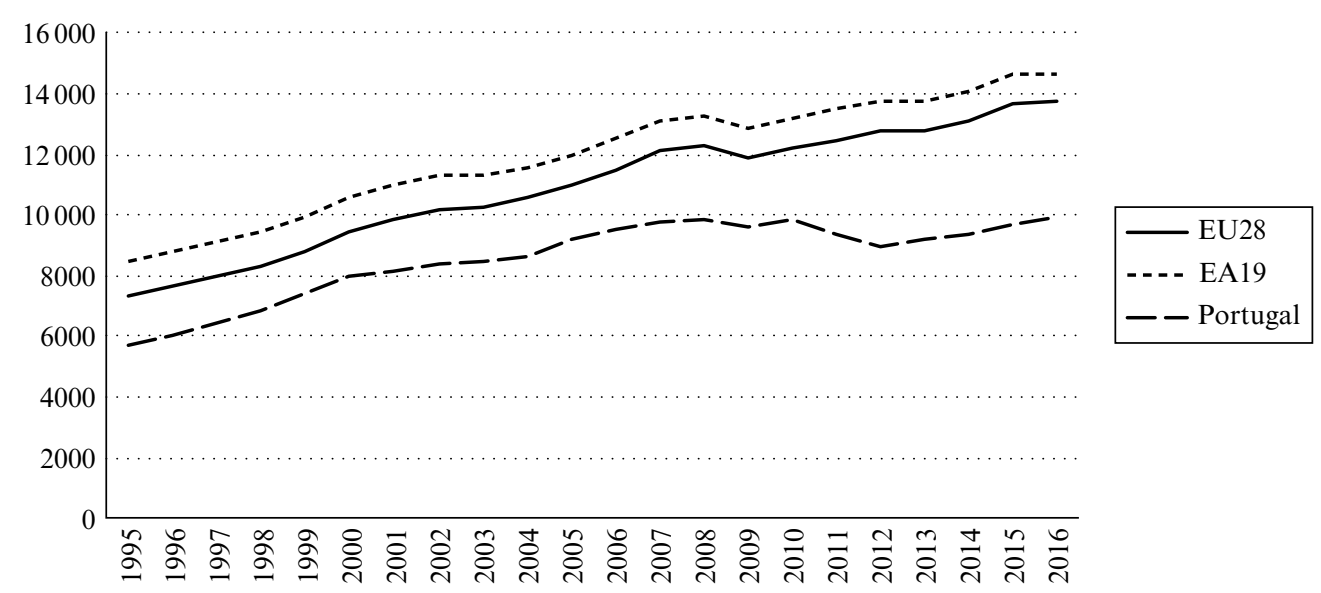

Source: PORDATA.

Figure 9.17 Wage earnings per capita (PPS), EU19, EU28 and Portugal, 1995-2016

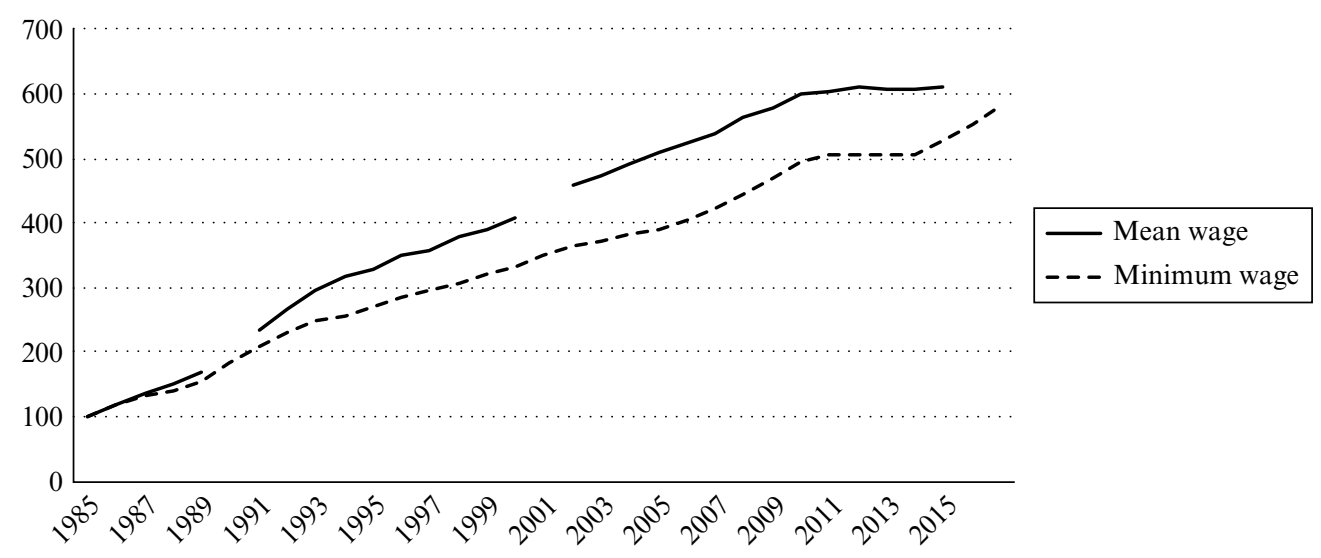

Source: PORDATA.

Figure 9.18 Mean and minimum monthly wage, Portugal, 1985-2015 (1985=100)

\subsection{Income Inequality and Polarised Income Distribution}

Portugal has a low income level by EU standards (Figure 9.21) and high and persistent income inequality (Figure 9.22). A process of convergence towards the EU mean was visible in the first decade of the 2000s but was interrupted by the financial and economic crisis. Figure 9.22 shows that after 2009 the convergence of the Gini coefficient was interrupted, although it is still not clear whether the ongoing recovery will again be followed by falling inequality. 


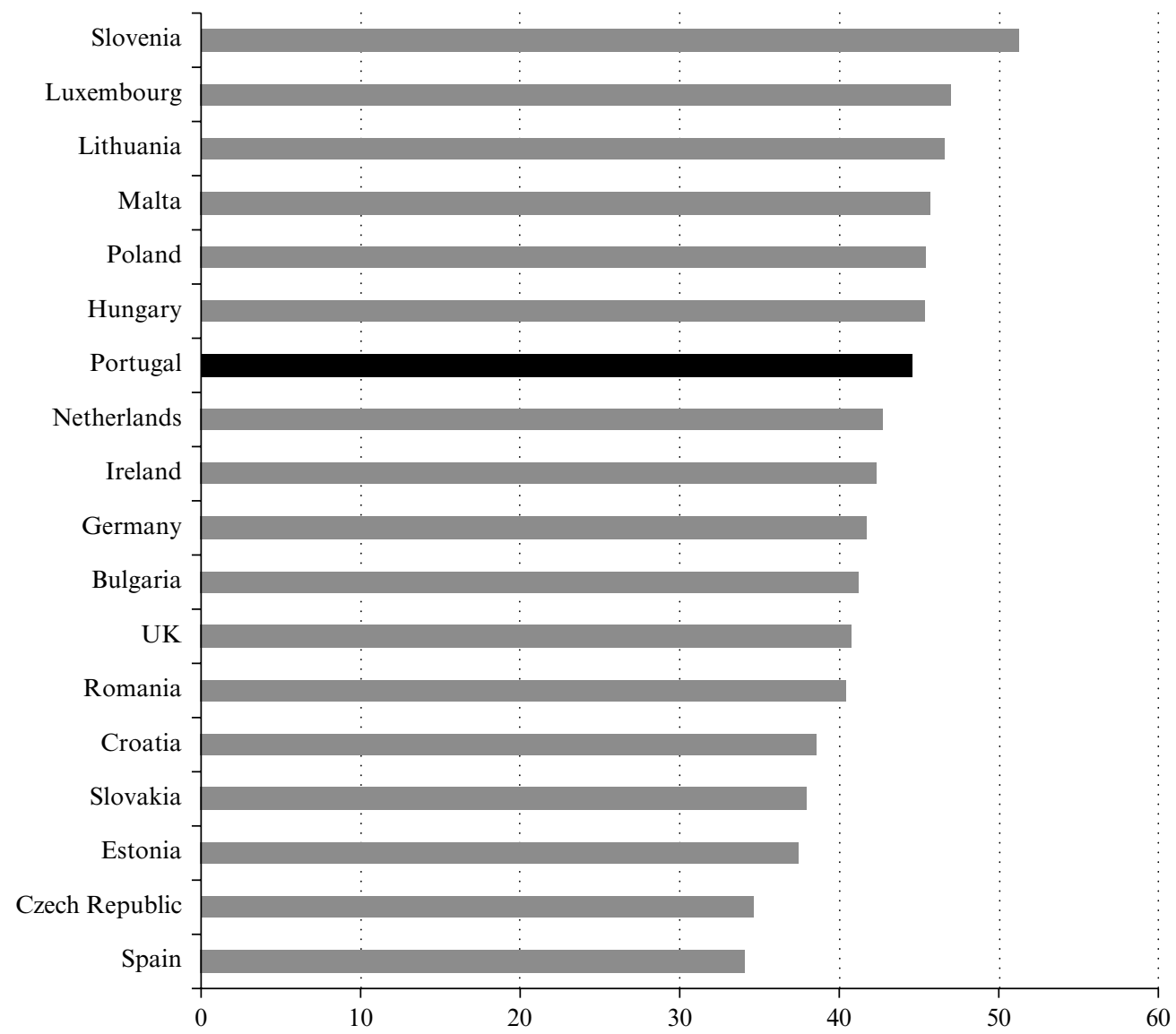

Source: Eurostat.

Figure 9.19 Monthly minimum wage as a proportion of average monthly earnings, Portugal and EU member states (percentage)

It is important to stress that income distribution in Portugal appears to be quite polarised in EU terms. Figures 9.23 and 9.24 compare the P90/P10 (used as a measure of inequality in the upper part of the income distribution) and the P50/P10 (used as a measure of inequality in the lower part of the income distribution) for two groups of EU countries. Three main aspects must be highlighted: (1) inequality is particularly high in Portugal in the upper tail of the income distribution; (2) inequality at the bottom, high by northern European standards, is significantly lower than in other southern European countries; and (3) the crisis had a noticeable impact on increasing inequality at the bottom but not at the top of the income distribution.

Still - and following González et al. (2016) - it is important to note here that middleincome groups appear to have been particularly resilient in Portugal in terms of their income share during the period of the crisis, enjoying relative success by EU standards. 


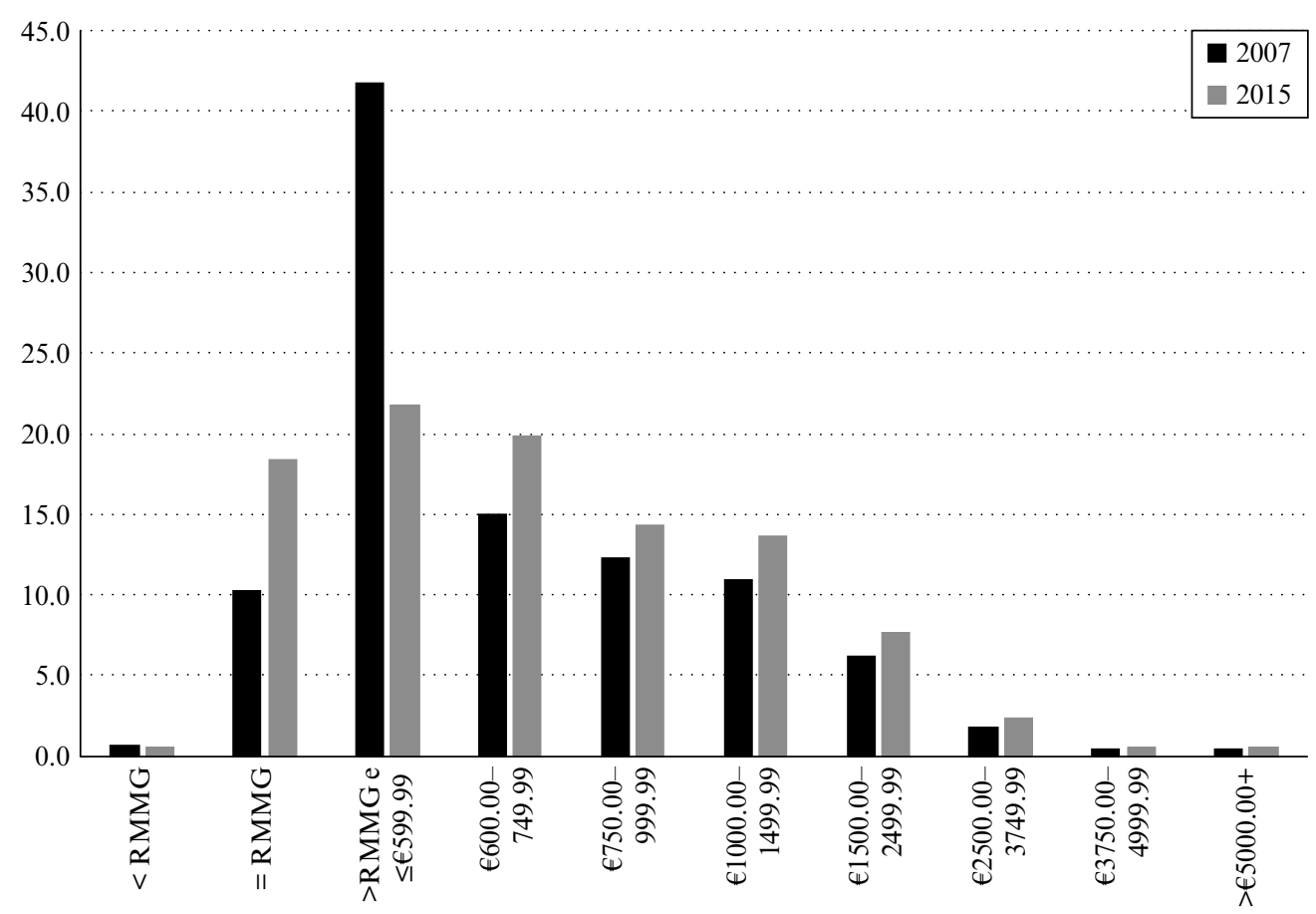

Source: Portuguese Ministry of Labour (GEP/MTSS).

Figure 9.20 Wage distribution in Portugal, 2007 and 2015

These groups experienced lower income losses in the period of the bailout. This indicates some success on the part of the progressive tax system and social transfers in performing their redistributive roles, although low-income groups were penalised together with higher-income groups. However, González et al. (2016) also argue that, given the high inequality in Portugal, the low absolute level of household income and the comparatively smaller size of the middle class (by income) this resilience is only partial.

\subsection{Poverty and Social Inclusion}

The at-risk-of-poverty rate has been high in EU terms and again the recent crisis interrupted the very slight decrease that has been observed since the mid-2000s (Figure 9.25). But what importance is accorded poverty rates in Portugal within the framework of industrial relations and social dialogue? The level of unemployment and the incidence of low pay are, together with the educational shortcomings of the unskilled, significant factors of social exclusion in Portugal (González et al. 2016). Poverty issues are thus, at least indirectly, always present on the social dialogue agenda.

In-work poverty, which is high in Portugal, has been is increasing in the EU as a whole since the crisis (Figure 9.26). Again, the convergence that was visible in the early 2000s has been interrupted by the recent crisis. 


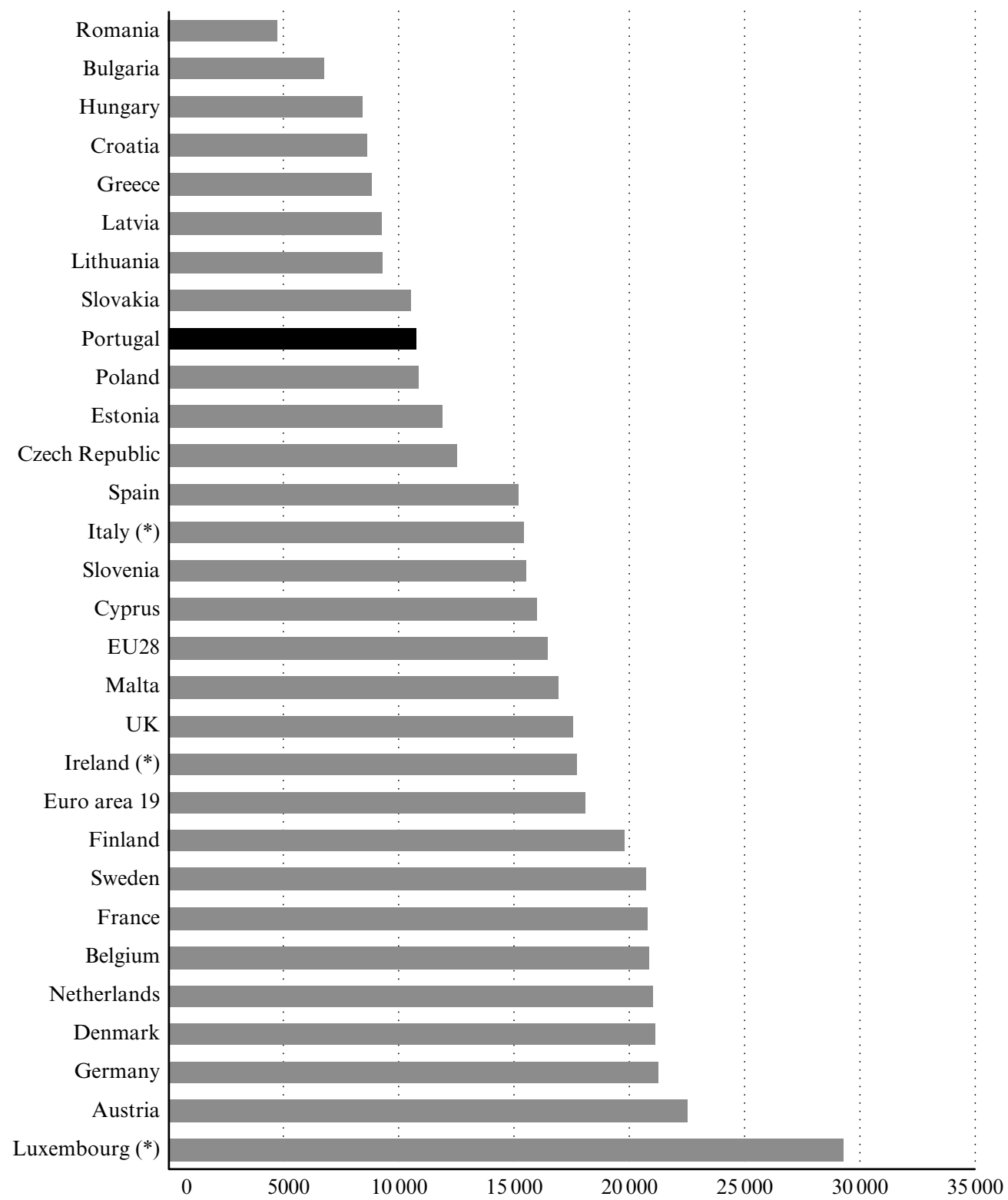

Note: $\quad\left({ }^{*}\right)=2014$.

Source: Eurostat.

Figure 9.21 Median equivalised net income in Portugal and the EU, 2015 


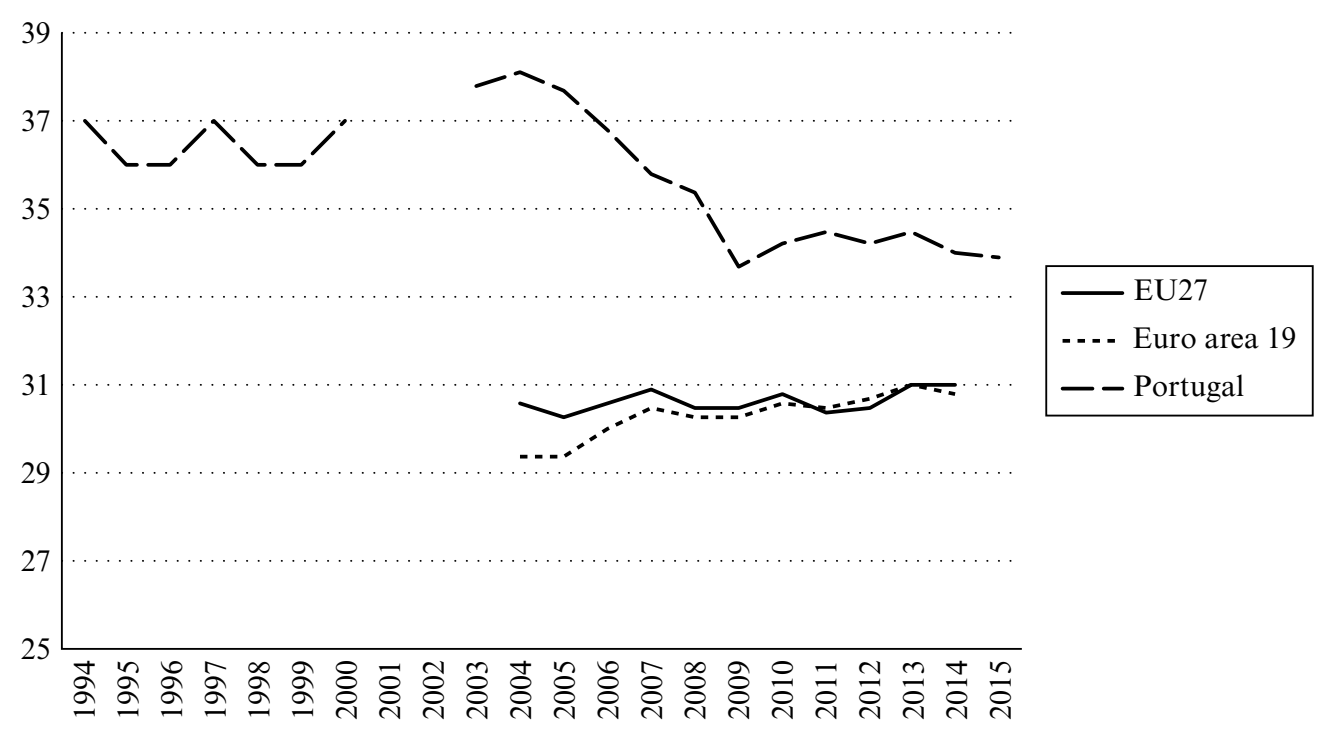

Source: Eurostat.

Figure 9.22 Gini coefficient of equivalised disposable income, Portugal and EU27, EU19 euro area and Portugal, 1994-2015

\subsection{Education as a Means of Social Mobility}

Portugal ranks first among EU member states in terms of the low educational level of its population measured by the relative importance of only primary-school educated individuals in the working-age population (Figure 9.27). ${ }^{30}$

The educational deficit appears to be one of the main structural characteristics of Portuguese society and labour market. Relevant signs of convergence to EU levels have been visible in recent years, resulting from the high social investment in this area (Figure 9.28). It cannot be said that the crisis and bailout adjustment halted social investment in education in absolute terms. However, the budgetary consequences of fiscal consolidation led to significant difficulties in maintaining high social investment in education. The cuts in teachers' wages, the interruption of career progressions and the corresponding problems with motivation, and the limits imposed on public investment in school infrastructure illustrate the constrained circumstances. Given the persistence of a substantial gap, the bailout adjustment, although not halting social investment in this area, significantly compromised the need to maintain a persistent convergence trajectory.

At least three social pacts were signed in the 2000s (2001, 2005 and 2006) on education and, mainly, on-the-job training, recognising 'the existing school and training deficits of the Portuguese labour market [that represent a key hindrance] to firms' competiveness, job creation and improvements in working conditions' ${ }^{31}$ 


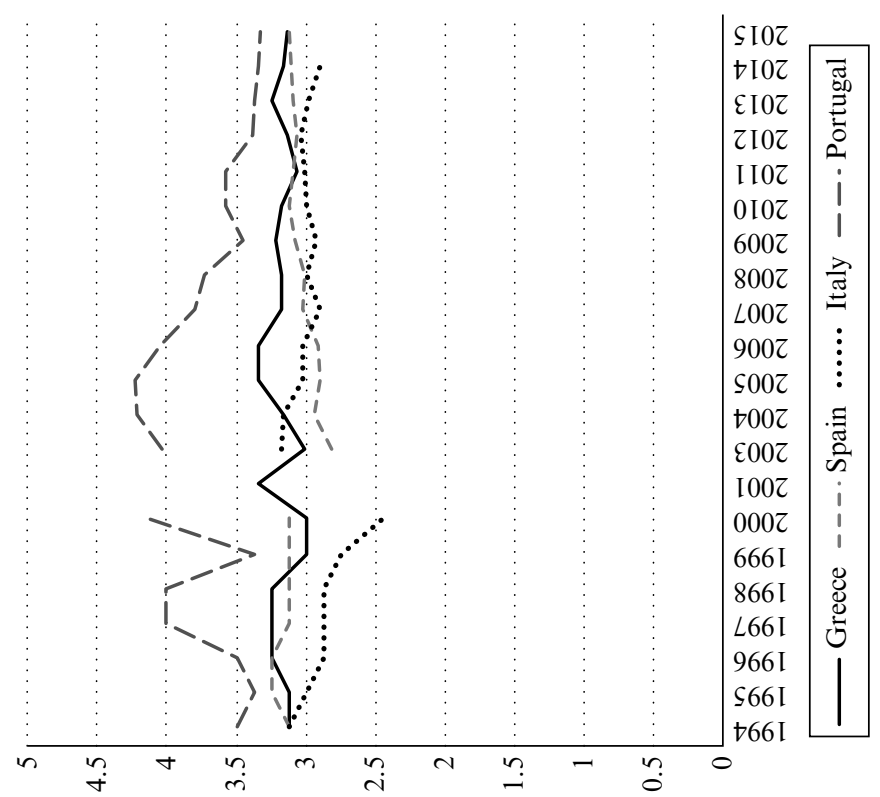

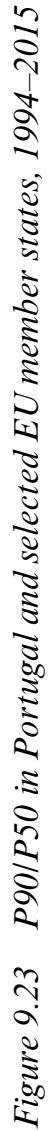




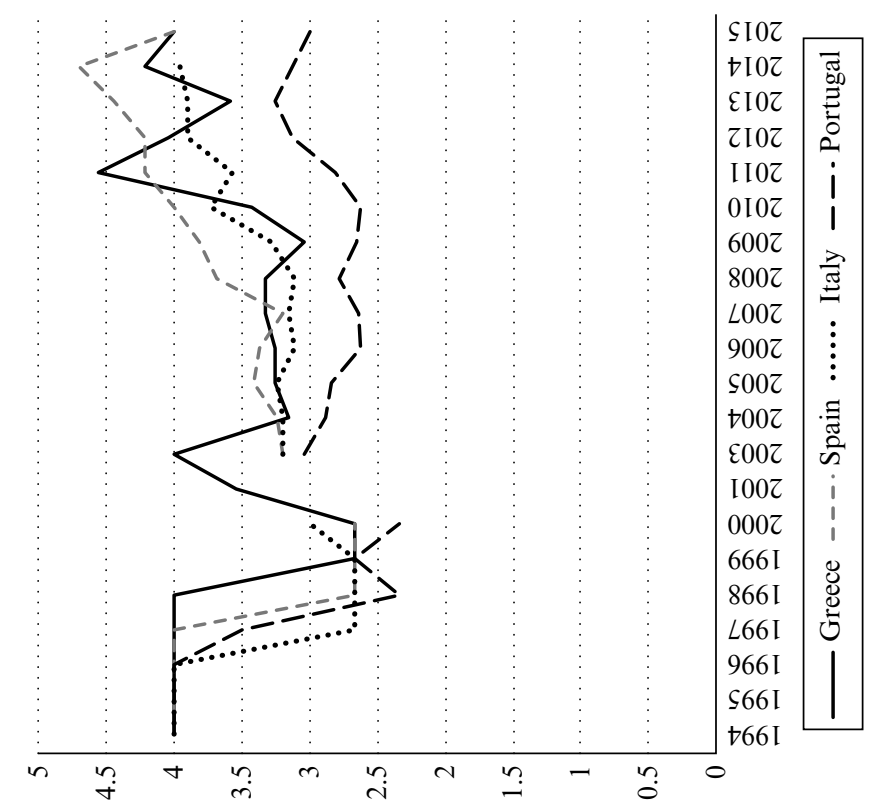

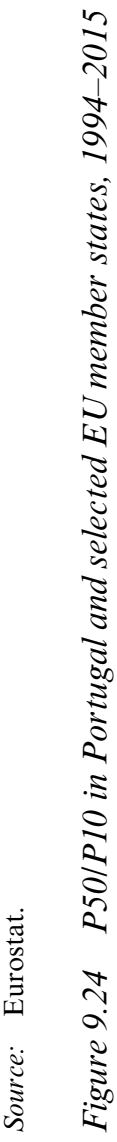




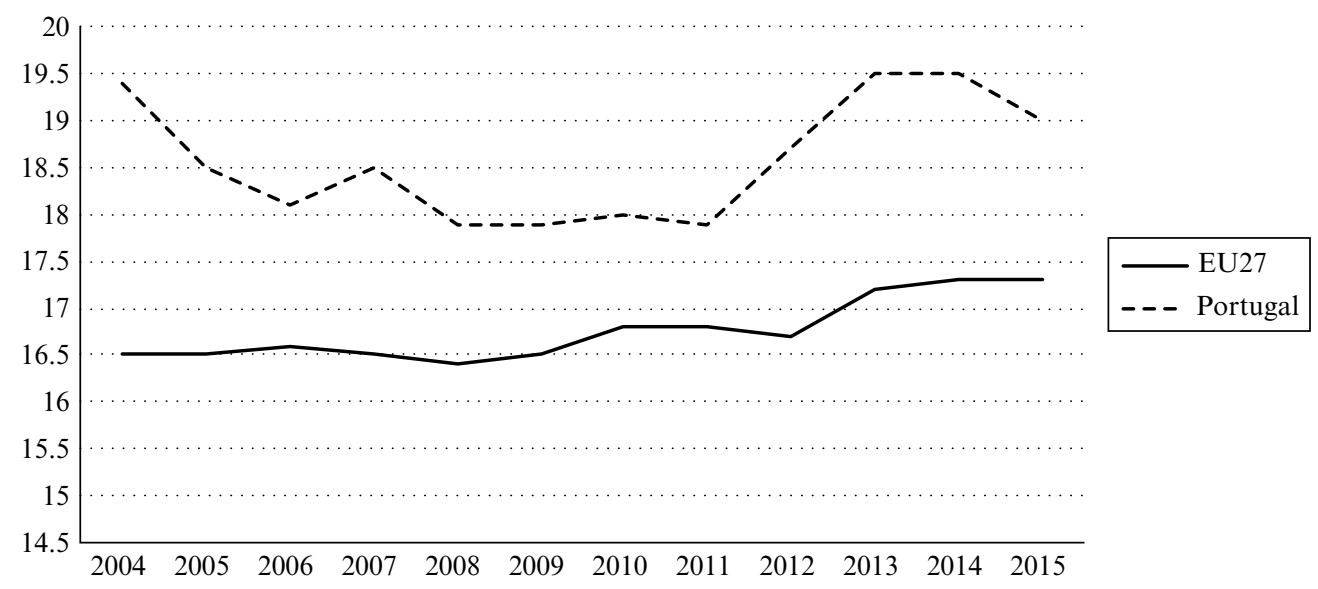

Source: Eurostat.

Figure 9.25 At-risk-of-poverty rate, Portugal and EU27, $2004-2015$ (percentage)

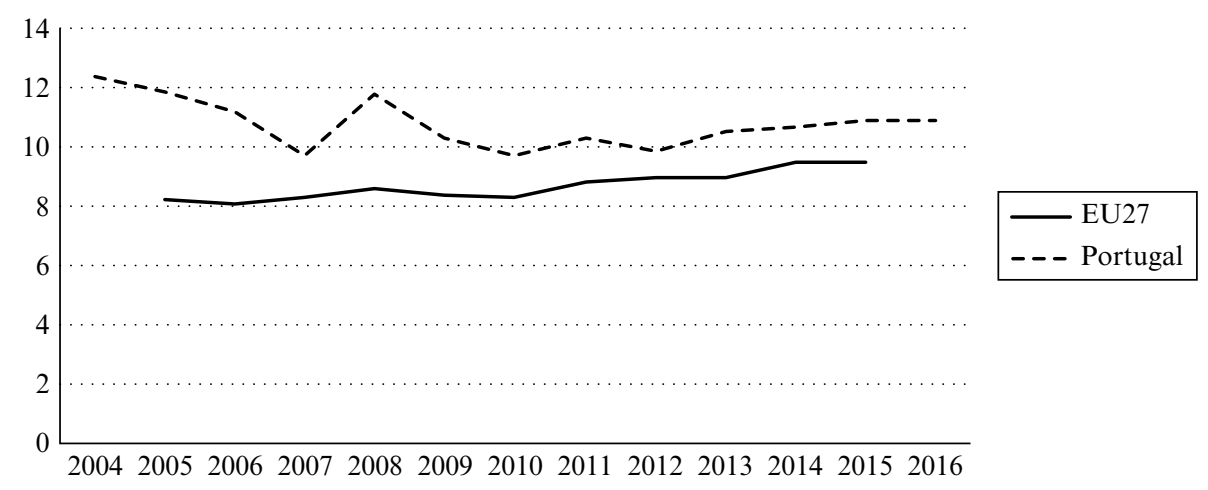

Source: Eurostat.

Figure 9.26 In-work at-risk-of-poverty rate, Portugal and EU27, 2004-16 (percentage)

\subsection{Industrial Relations and Social Convergence}

\subsubsection{Collective bargaining and the labour market}

In the 44 years since democracy was restored, social dialogue and collective bargaining have experienced periods of discontinuity but have also reflected the influence of political party disputes. Interpreting the development of the labour and capital shares in income distribution as a proxy of the balance between the political influence of capital and labour shows that in periods of falling labour share - such as the bailout austerity period - social dialogue and collective bargaining tend to be weaker. Currently, no research is available in Portugal that extends the analysis of Piketty and Zucman (2014) on the development of 


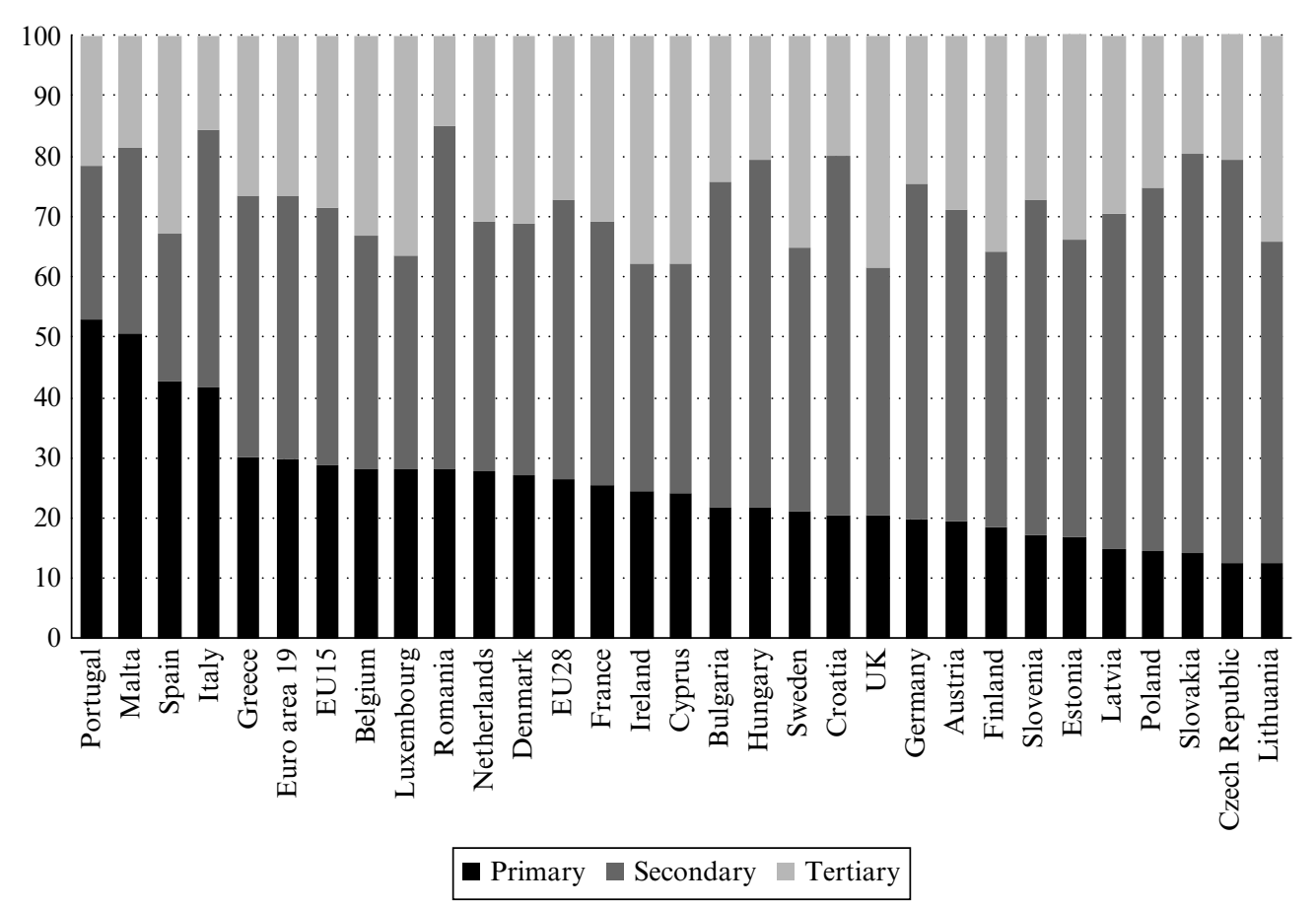

Source: Eurostat.

Figure 9.27 Structure of population by educational level, Portugal, EU19 euro area, EU15, EU28 and EU member states, 2016

indicators such as the wealth:income ratio and of capital and profit shares, or on its most recent developments as presented by Eggertsson et al. (2018), who explore the effects of concentration and monopoly in inequality. The new variables used in that research could enable a better understanding of the influence of inequality patterns in Portugal on the strength (or weakness) of social dialogue and collective bargaining.

That said, it is very important to underline the perverse effect of discontinuity in social dialogue and collective bargaining over the Portuguese economy's need for structural change. The difficult and painful transition from a competitiveness model led by cheap and abundant labour towards another one led by innovation, skilled labour and demographic decline cannot be achieved without a strong investment in social dialogue able to create an adequate level of trust among the social partners. Restoring trust is crucial in establishing more stable horizons for investment and ensuring that the wage structure reflects the slow but sustained increase in better qualified and skilled youngsters entering the labour market.

As shown by González et al. (2016), young skilled workers are entering the Portuguese labour market with a much higher level of education than that of those already employed. To enable this increased level of skills to contribute successfully to the needed transition to a competitiveness model led by innovation and high-skilled jobs, returns to 


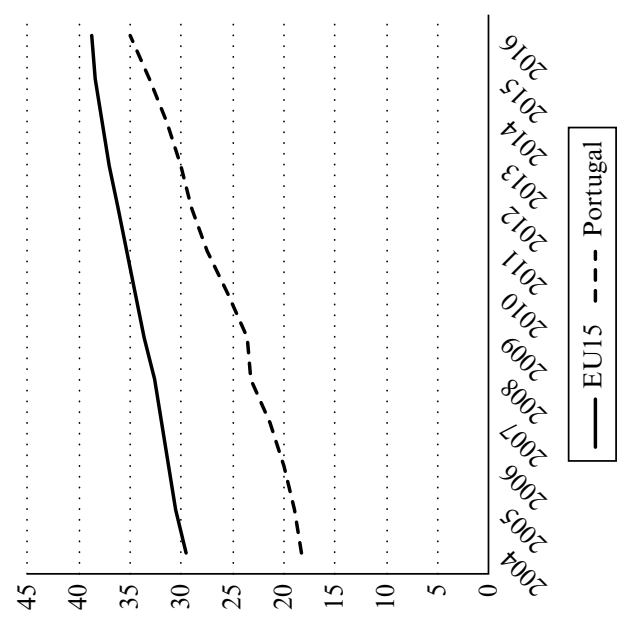

$\frac{0}{\overparen{2}}$

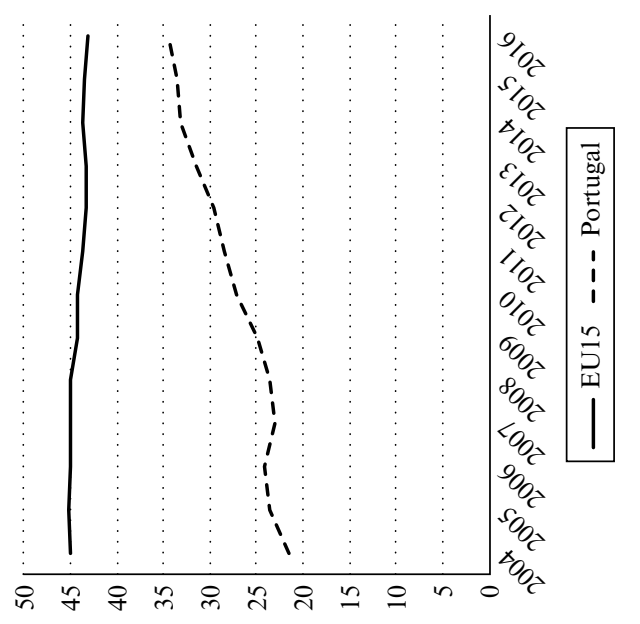

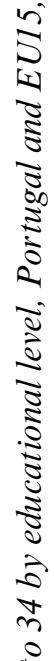

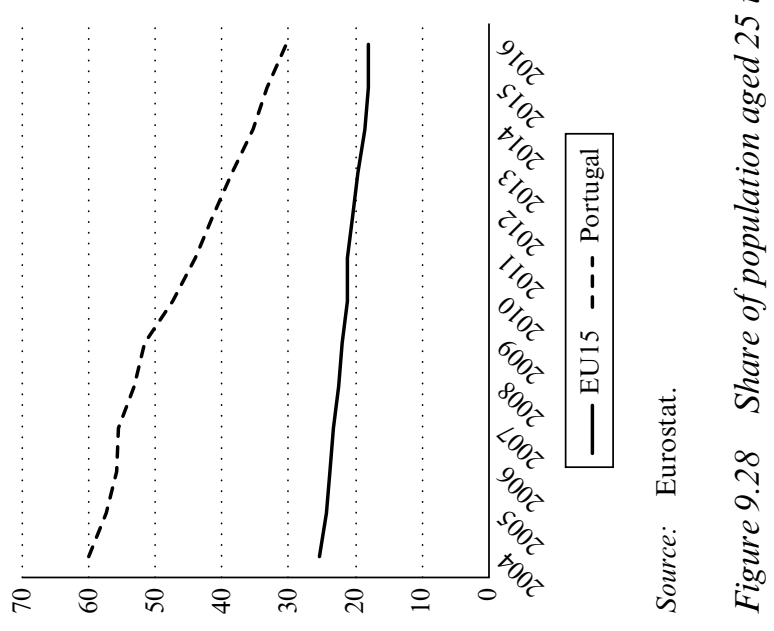


higher education must come to be generally perceived as positive. ${ }^{32}$ The social partners and social dialogue can have an important role in enhancing the positive effects of education. In 2006 an important agreement was reached on reforming the training system, one of the few signed not only by the four employers' confederations, but also by the two unions' confederations (the UGT and the CGTP - the latter normally does not sign social agreements). This agreement was an important milestone in achieving social dialogue consensus on labour qualifications and generating important results in collective bargaining. The contribution of continuous training to employment and well-designed retraining for the unemployed both have to be seen as convergence factors. Sustainable agreement is needed on the importance of workers' training and qualifications as a basis for the changes needed in production. After rebalancing relations between employers and employees, there is considerable room in social dialogue for further agreements targeted at these objectives.

The argument can be extended to the needed balance between labour market flexibility and security. The Portuguese labour market is known to have very restrictive legislation according to the OECD index of strictness of employment protection (SEP). However, it is important to note that, in recent decades, rigidity in temporary contracts and collective dismissals have been sharply reduced: with regard to the SEP and temporary contracts the index fell from 2.81 in 2000 to 1.81 in 2013 , only slightly above the OECD average value (1.72); as for the SEP concerning collective dismissals (additional restrictions) ${ }^{33}$ it fell from 2.88 in 2004 to 1.88 in 2013, well below the OECD average (2.90). The index that has the highest value is the SEP on individual dismissals (regular contracts): Portugal has the highest value of all OECD countries (3.18) compared with an OECD average of 2.04. However, it has to be stressed that almost all EU countries rank high on this indicator, especially the Netherlands (2.82), Germany (2.68) and Sweden (2.61). We must therefore show some caution with regard to the links between index rigidity and flexibility in the labour market. The evolution of labour legislation, and of its necessary adaptability to new dynamics in both the economic and the social system, cannot be an instrument for conjunctural adjustment. Stability of labour law is necessary to enable both workers and firms to plan for the future.

More than the changes (even if pertinent) that can be introduced in generally favourable conjunctures (for both workers and firms), a debate is needed on a stable approach to 'flexi-securitise' the Portuguese labour market and facilitate the transition to a new competitiveness model. From this perspective the trade-off between more secure temporary contracts and more flexible regular contracts has to be taken seriously.

It is obvious that labour market legislation cannot be isolated from the political imbalance between capital and labour. However, in the case of Portugal, the search for stability to attract and consolidate higher and upgraded levels of foreign direct investment cannot be promoted in a permanently changing labour law context. Because social dialogue and collective bargaining cannot ignore the need for the Portuguese economy to move towards a new competitiveness model, a balance must be sought between the capitallabour approach and competitiveness-led priorities.

In line with the search for balance, the high level of segmentation in the Portuguese labour market should be a top priority for a new social dialogue round. 


\subsubsection{Collective bargaining and social cohesion}

Social dialogue and collective bargaining should be seen as social cohesion mechanisms. The Portuguese experience is still in its infancy in these matters. Beyond the discussion on minimum wages, which is the most notable bargaining dimension, there are other central debates in line with social cohesion objectives. For example, reconciliation between work and family life is a gender-driven discussion considered to be decisive in reducing the gender gap in the labour market but also to allow a higher level of fertility. The efforts to increase the fertility rate in Portugal, one of the lowest in the industrialised world, should be interpreted as a national priority to which everybody must contribute. Social dialogue and collective bargaining are pertinent institutional spaces for ensuring that employers also contribute to this national objective. Firms' receptiveness to more flexible regimes that provide for a more balanced reconciliation of work and family life should be seen as a social contribution to the recovery of fertility rates.

Reducing conflict and tightening links between employers and workers through social dialogue is also a source of social cohesion likely to encourage a more stable investment context.

Last but not the least, inequality in income distribution and poverty cannot be marginalised or ignored in social dialogue. All the research shows that, in Portugal, low education, low wages and unemployment, often generating interdependent effects, are the main sources of poverty. The risk of poverty is directly or indirectly linked to labour market performance and thus cannot be kept out of the scope of social dialogue.

\section{CASE STUDY 1: GENDER EQUALITY AND COLLECTIVE BARGAINING}

Gender equality has been at the forefront of European employment policy since the early 1990s. Convergence as regards gender equality is a necessary dimension of social convergence among EU member states.

Several analytical dimensions are at issue when gender equality is put on the agenda: activity and inactivity gaps (and the need to include in the analysis the reconciliation of work and family life), employment and unemployment gaps, and pay gaps.

\subsection{Recent Evolution of Gender Equality on the Portuguese Labour Market}

Since at least the 1970s, the Portuguese labour market has had a high female participation rate by EU standards. Figure 9.29 shows a pattern that clearly differentiates Portugal from the other EU15 member states: Portugal combines a high female activity rate with a low incidence of female part-time employment. ${ }^{34}$

Gender employment and unemployment gaps exist in Portugal as in other member states and the effects of the recent crisis show up very clearly in Figure 9.30. However, compared with the EU15 average, the gender gap in employment rates remains lower in Portugal. In Portugal, similar to the EU15 average, the gender unemployment gap had been falling and eventually disappeared during the crisis.

As in the other EU member states, employment in Portugal remains highly segregated by gender, regarding both sectors and occupations. 


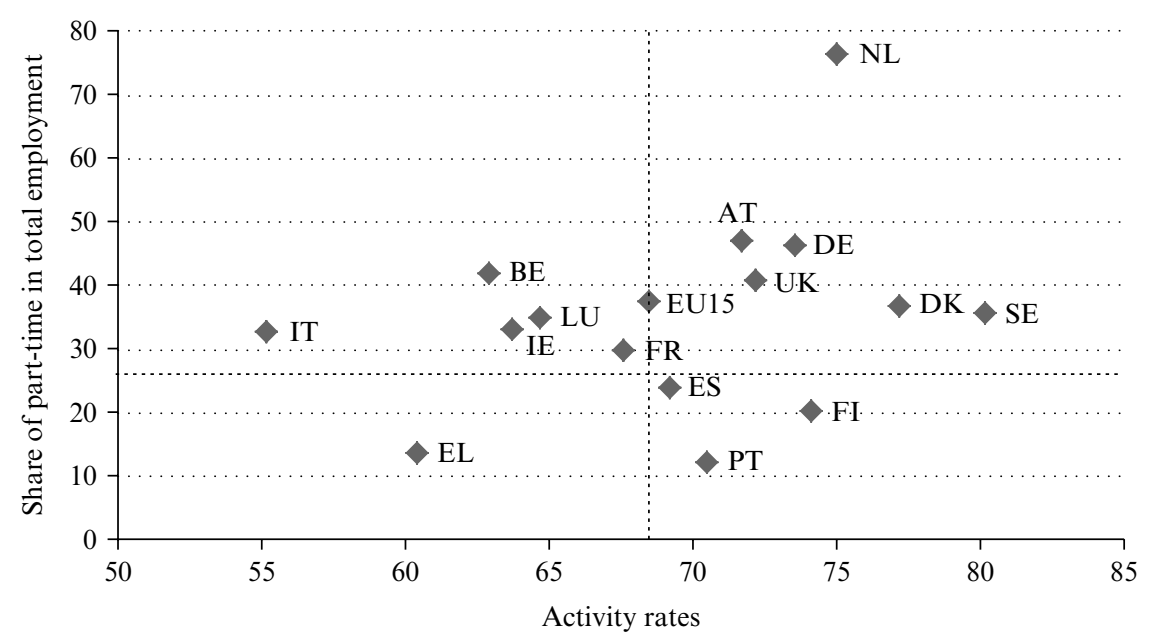

Source: Eurostat.

Figure 9.29 Activity rate and share of part-time in total employment, women, Portugal and EU15, 2016

The gender wage gap (Figure 9.31) is above the EU average and, according to several studies (for example, González et al. 2009), is highly dependent on sector and occupation. Also, as shown in Figure 9.32, it strongly increased during the crisis, in contrast with a fairly stable evolution in the EU28. Thus a diverging process as regards gender gaps is also visible, associated with Portugal's recent development.

\subsection{Is Collective Bargaining Concerned with Gender Equality?}

Gender issues have traditionally been absent from the industrial relations discussion. ${ }^{35}$ Yet the higher visibility of gender inequalities seems to be opening up some space for introducing this dimension into collective bargaining. Recently, in Portugal, a new collective agreement in the footwear industry signed in April 2017 integrated the gender wage gap in the discussion and agreed a new wage grid eliminating gender wage gaps.

The footwear industry is highly dominated by female workers (Table 9.1). However, despite the fact that in Portugal, as in other EU countries, manufacturing has a lower concentration of female workers as regards the average labour market, some sectors within manufacturing remain highly feminised, such as textiles, clothing and footwear. The data also clearly show that the gender wage gap in this sector is clearly above the average wage gap in the labour market.

Since discrimination is unconstitutional in Portugal, the differences in wages are mainly due to female-dominated occupations being paid less than functionally equivalent maledominated occupations. Since 2016, the union federation (FESETE) and the employers' association (APPICAPS) in the footwear sector have started negotiations to eliminate gender differences in similar-level occupations and, after a deep reorganisation of categories, signed a collective agreement in 2017 in which those differences were eliminated. 

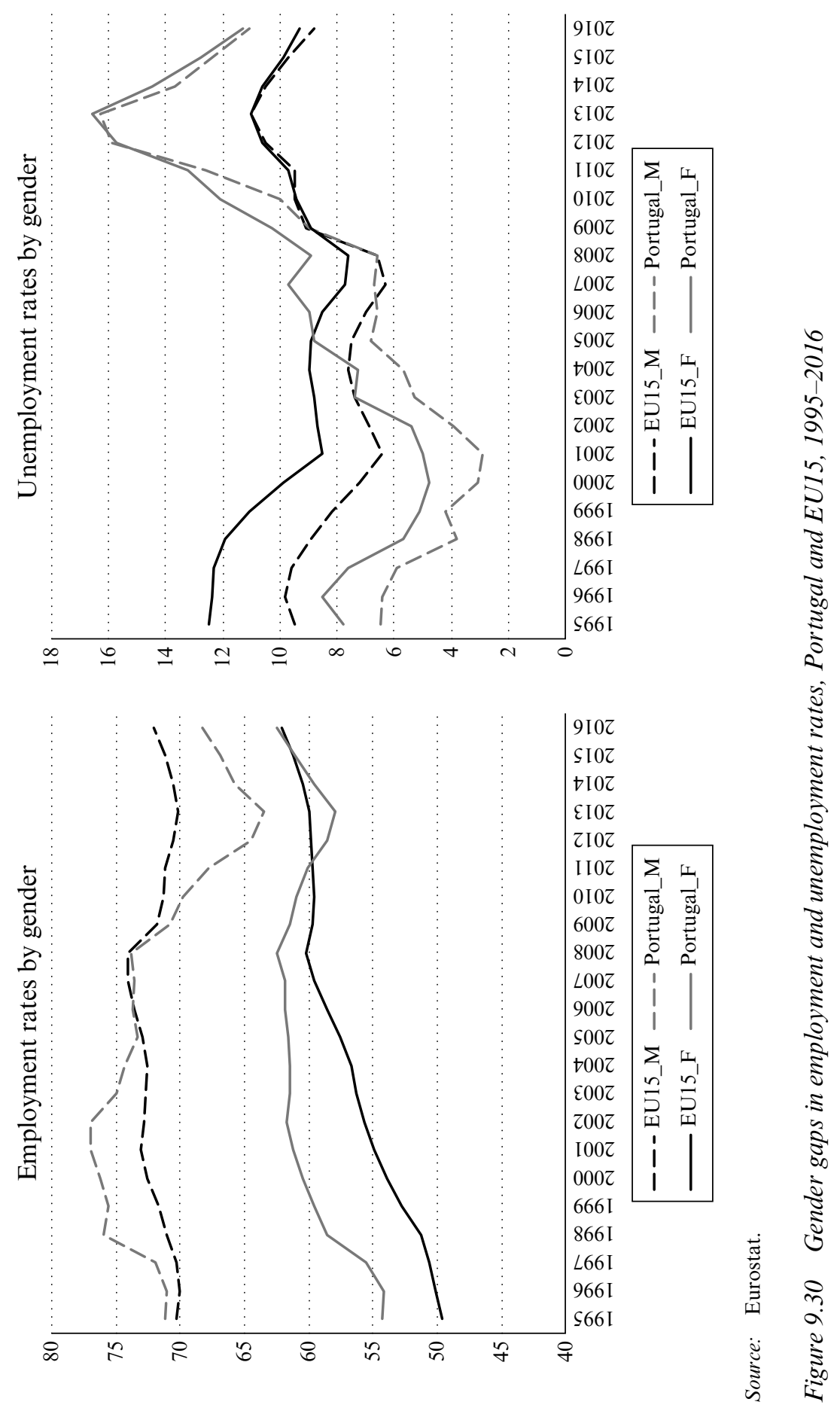


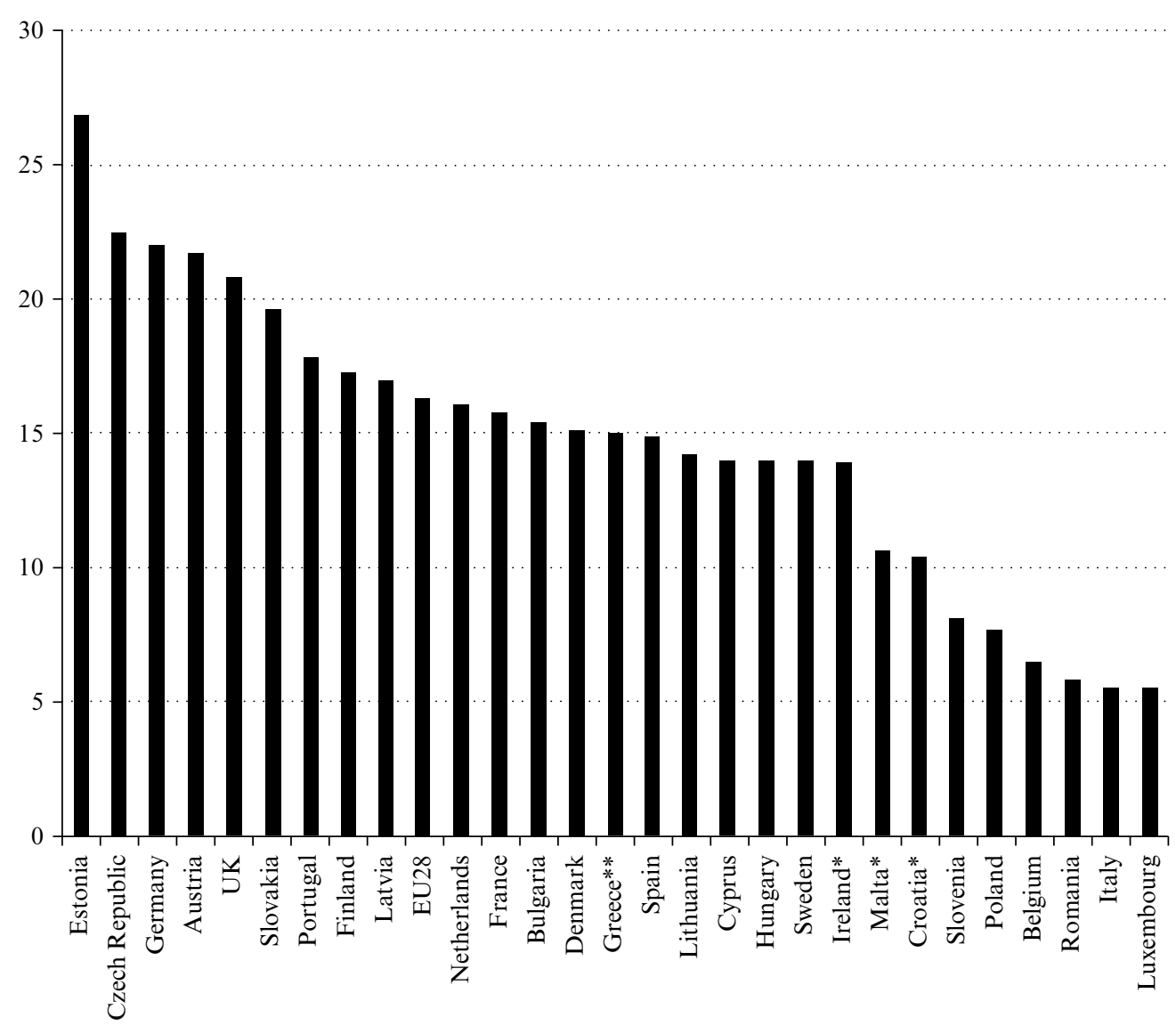

Notes: * 2014; **2010; data refer to Industry, construction and services (except public administration, defence, compulsory social security).

Source: Eurostat.

Figure 9.31 Gender pay gap in unadjusted form, Portugal and EU member states, 2015

According to the trade union federation for the footwear industry:

[it is] very important and a matter of basic justice to eliminate discrimination regarding occupations and the wages of predominantly female jobs. After serious and deep research on this topic in 2016 and 2017 FESETE and its affiliated unions were able to negotiate with APPICAPS the eradication of such unfair discrimination that has long affected women in this sector. ${ }^{36}$

The employers' association described the agreement as 'historic' as it achieves, for the first time, equal pay for workers of equivalent categories independent of gender. ${ }^{37}$

This agreement was widely reported in the media ${ }^{38}$ and the Minister of Labour himself was present at its signing in order to signal the importance the government attaches to such a novel initiative. He stated that it is not only another collective agreement but 


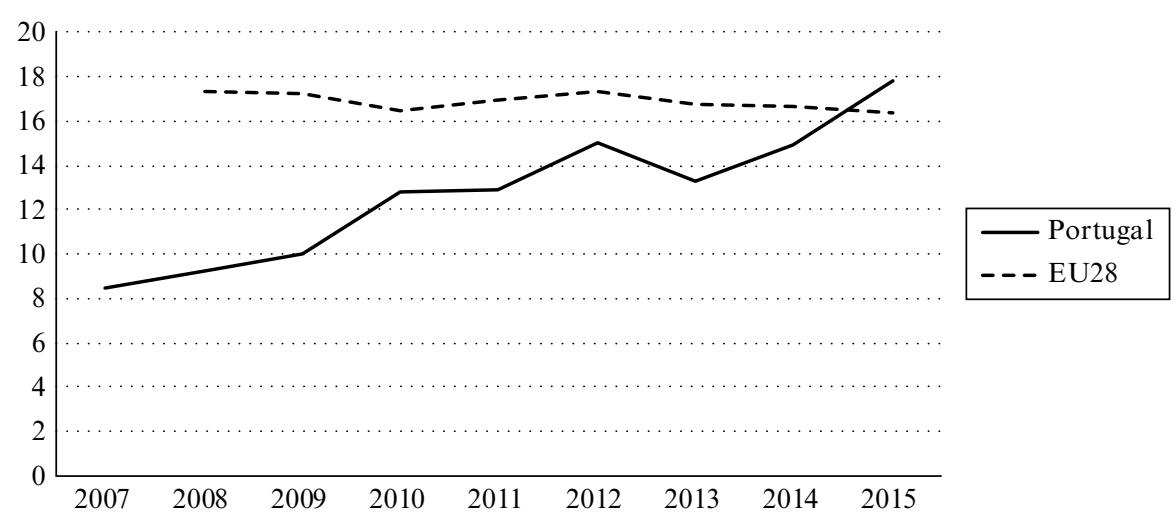

Source: Eurostat.

Figure 9.32 Gender pay gap in unadjusted form, Portugal and EU28, 2007-15

Table 9.1 Share of women in employment and gender wage gap in Portugal, 2016 (percentage)

\begin{tabular}{lcc}
\hline & $\begin{array}{c}\text { Share of women in total } \\
\text { employment }\end{array}$ & Gender wage gap \\
\hline Total & 48.2 & 18.7 \\
Manufacturing & 42.7 & 30.4 \\
Textiles, clothing and footwear & 68.7 & 27.4 \\
\hline
\end{tabular}

Note: Data refer to the private sector of the Portuguese economy. The gender wage gap is obtained as follows: (male mean wage - female mean wage) / female mean wage.

Source: GEP/MTSS, Quadros de Pessoal 2016 - Síntese.

rather an innovative one as it combats gender discrimination'. ${ }^{39}$ Social actors in other sectors have been encouraged to promote similar initiatives.

\section{CASE STUDY 2: CENTRALISED OR DECENTRALISED INDUSTRIAL RELATIONS SYSTEMS?}

Decentralisation of the industrial relations system entered the public debate mainly in the aftermath of the financial and economic crisis and the intervention of the Troika. One of the reforms included in the Memorandum of Understanding (MoU) was the 'organised decentralisation' of the collective bargaining system. As referred to in the MoU, the importance of such decentralisation had already been recognised in a tripartite agreement signed between the Portuguese government, the employers' confederations and one of the union confederations a couple of months beforehand. The text of the MoU states: 
[the Portuguese Government will] implement the commitments in the Tripartite Agreement of March 2011 concerning 'organised decentralisation', notably concerning . . . the possibility for works councils to negotiate functional and geographical mobility conditions and working time arrangements; . . the lowering of the firm size threshold above which works councils can conclude firm-level agreements to 250 employees. ${ }^{40}$

The tripartite agreement in question (CES 2011, pp.22-3) refers to these issues, but also explicitly states that 'the predominance in Portugal of micro and medium firms implies that, in order to maintain the high coverage rate of collective agreements, sectoral collective bargaining has to maintain an important role in Portuguese industrial relations'. This statement refers to two central issues for the Portuguese social partners within the framework of the decentralisation process: first, decentralisation should mean developing both firm and sectoral bargaining; and second, decentralisation should be accompanied by high coverage of collective agreements.

\subsection{Should We Decentralise the Industrial Relations System? What Are the Costs and Benefits of Such Decentralisation?}

The rationale for decentralising collective agreements is based on the importance of conferring autonomy on social actors at the firm level to decide on certain domains regulated at the sectoral level. These issues include mobility, organisation of working time and functional adaptability, and are aimed at enabling firm-specific adjustments in order to increase adaptability at the firm level, while also accommodating workers' needs and interests. At firm level, both the employer and the workers have more information on the specific needs of the firm, which makes possible better designed solutions. These issues are on the plus side of decentralisation.

However, we have to be aware that proximity of employee and employer can induce contradictory dynamics. Proximity, in a context of trust, can give rise to creative solutions for the organisation of work; but in a context of more authoritarian labour relations, it can reduce the power of workers' voice. This has to be counted among the potential costs of decentralisation.

In a recent study (Távora and González 2016a) of the Portuguese industrial relations system in manufacturing, three distinctive models of management practice at the firm level were identified:

1. Authoritarian models, related to a management stance of open hostility towards unions ('if you are a union member you are not welcome in the firm' or other more moderate, but equally unfriendly positions).

2. Paternalistic models, related to practices in which certain forms of social dialogue are promoted but firms represent workers as 'not really understanding reality' and so in need of 'guidance' by managers. Frequently in these firms norms of 'gift exchange' are prevalent in labour relations.

3. Dialogue models in which managers and (elected) workers' representatives represent social dialogue and access to information as essential for the quality of labour relations. Dialogue between managers and workers is effective and based on mutual respect, mutual concessions and innovative outcomes. These models are more prevalent in big firms but have also been identified in small firms. 
We must then be aware that different management practices impose different constraints on the outcomes of decentralisation.

It is also clear in Távora and González (2016) that diverse negotiation practices exist in different workers' organisations operating at the firm, sectoral and national levels in Portugal:

- Some workers' organisations are rigid, hostile towards management and distrustful of negotiation.

- Others appear to be much more flexible and open to negotiation (with regard to what is considered negotiable).

- Despite workers' organisations affiliated to the CGTP (the bigger, older trade union confederation, close to the Communist Party) normally being more rigid and those affiliated to the UGT (more in the political centre, represented by the Socialist and the Social Democratic parties) being more open to negotiation, it is clear that, at the sectoral and firm levels, this association is much looser, with CGTP-dominated workers' committees and unions being, in some cases, involved in open and innovative dialogue, as in the case of the footwear sector (see Case Study 1 in section 3).

- Evidence of very strong hostility between different union representatives has also been collected, particularly at the sectoral level, making the attainment of trust among the social partners more complex.

It is important to note all this to identify the potential costs of decentralising collective bargaining. The positive potential of the process might come to nought in a context of highly conflictual, hostile and mistrustful labour relations. Also, and as stressed in CES (2011), the composition of Portuguese firms (micro-firms account for 95.3 per cent of total firms and 41.2 per cent of total employment, compared with 92.8 per cent and 29.8 per cent in the EU28 ${ }^{41}$ ) favours the combination of centralised and decentralised bargaining levels since, in small firms, formal negotiations at the firm level hardly exist.

\subsection{Empirical Evidence on Novel Initiatives Involving the Decentralisation of Collective Bargaining}

When we discuss employee representation in the workplace in Portugal, the case of Auto-Europa is normally raised. Auto-Europa is a car manufacturer that belongs to the Volkswagen group and is considered a 'paradigmatic but atypical case of good industrial relations and firm-level bargaining in Portugal' (Távora and González 2016a, p. 357).

[T] he atypical character of industrial relations in the firm lies not only in their unusually collaborative nature but also in the fact that the negotiating party from the workers' side is the workers' committee, which signs company agreements without the mandate of the sectoral union. For this reason, these agreements are not legally enforceable but they have effectively regulated the organisation of work, and the terms and conditions of employment in the firm since 1994, while contributing to industrial peace. The character of industrial relations in this company is, however, strongly influenced by those of the German parent company. Under that influence, management is highly supportive of regular communication and transparent sharing of information that supports a culture of cooperation and trust. (Távora and González 2016a, p. 357) 
The influence of the German industrial relations system in this particular firm is often emphasised as its participatory and cooperative characteristics differ from those in other big Portuguese firms.

Union density in the firm is high and there is high participation in elections for the workers' committee, involving normally 70 to 90 per cent of the firm's employees.

Several agreements have been reached at the firm level in recent decades, introducing innovative solutions for the particular needs of the firm, including a system of timebanking first introduced in 2003 - long before its inclusion in the Labour Code in 2009 - and further developed in 2012.

Recently, together with the installation of a newly elected workers' committee, there has been an increasing level of conflict in the firm. Whether the two are connected is currently a topic of controversy. The main issue of disagreement concerns extra work at the weekend, which has stimulated an interesting public debate on the reconciliation of work and family life. One of the main issues is the difficulty of finding childcare services at affordable prices at weekends.

Auto-Europa is often considered a good example of the benefits of decentralisation. However, replicating this experience at other Portuguese firms has been difficult, despite other good experiences of firm-level collective bargaining in big firms. But we should not confuse decentralisation of collective agreements to the firm level when possible, which is positive, with downgrading sectoral collective bargaining. Collective bargaining at the sectoral level is crucial in Portugal, both for historical reasons and, fundamentally, because of the highly dispersed firm structure, with a very high incidence of small and very small enterprises, often with very traditional management. Sectoral collective bargaining thus appears to be an important means of achieving equity among workers and fair competition among firms.

\section{CONCLUSIONS}

Convergence towards the EU average, in Portugal, is strongly determined by the country's recent history. From 1974, Portugal had to build a democratic society, a welfare state and a sustainable and open economic system. This has been strongly influenced, as has industrial relations, by the legacy of the autocratic regime and a revolutionary transition.

Portugal joined the EU in 1986, at which point it was well below the EU average in terms of economic indicators (per capita GDP) and social indicators (namely, education, poverty, income inequality and wages).

The gaps have remained wide, but recent trends show important changes. The recent crisis (felt in Portugal mainly after 2009) interrupted a convergence trend characterised by a number of social indicators (even if without a clear convergence path as regards economic convergence).

In the first decade of the 2000s, convergence towards the EU average was visible in terms of income inequality, poverty rates and education. However, the crisis and bailout of the Portuguese economy clearly interrupted this convergence process. Also, the crisis introduced a marked divergence in GDP per capita and in the main labour market indicators, namely, unemployment and employment rates and wages. This evidence shows how social convergence can hardly be dissociated from economic convergence and the 
sustainability of the Portugal's competitiveness model in the euro zone. Indeed, it shows that economic and social convergence should be combined.

The social convergence witnessed in the early 2000 s was accompanied by an accumulation of trust among the social partners by means of the enhancement of social dialogue at a centralised level. This increased visibility and recognition of the role of social dialogue contributed to important agreements between the social partners, allowing several reforms of labour law but also social recognition of the need to tackle certain structural deficits in the Portuguese labour market. Three aspects are particularly important:

1. Recognition of the low wages in Portugal and the need to increase them from the perspective of workers (to increase purchasing power, to avoid poverty and to ensure decent pay), but also from the perspective of employers (as sustainable competitiveness in a globalised world needs to go beyond competition based on low wages), contributed to the increased awareness of the importance of promoting wage increases for both social and competitiveness purposes and brought also to the public debate the importance of medium-term agreements as a basis for more informed decisions of both workers and firms.

2. Recognition of skill shortages and the need to invest in both education and training. Again, the acknowledgement of the importance of investing in education and training (in both the public and private sectors) and of its consequent positive effects for workers and for firms (for both social and competiveness improvements) has proved to be of the utmost importance;

3. Recognition of the need to maintain a healthy social security system, both because of the need to cover social risks adequately (unemployment and old age, among many others) and to ensure its sustainability. The increased awareness of the need for sustainability introduced into the public debate the issues of ageing and fertility. These issues have contributed to an increased awareness of the need to integrate gender equality and reconciliation of work and family life in the public debate.

The convergence process of the first decade of twenty-first century has other causes in addition to institutionalised social dialogue and the accumulation of trust by the social partners, as reflected in the various agreements and pacts. However, the latter have been key to developments.

The recent crisis and the intervention of the Troika represented an interruption of both the convergence process, in terms of most social and economic indicators, and investment in social dialogue (nevertheless, the previous accumulation of trust made possible two tripartite agreements in 2011 and 2012 that have been crucial for the climate of relative social peace that characterised the implementation of the Troika measures in Portugal). The period of Troika intervention was characterised by the suspension of social dialogue, culminating in the government's unilateral implementation of very strict criteria for the extension of sectoral collective agreements, which were strongly opposed by both unions and employers. This opposition is one sign of the weakness of a political approach centred mainly, or even exclusively, on individual firms and workers. Even though some aspects of decentralisation are important, they cannot substitute sectoral agreements. Instead, firms and sectoral collective agreements must coexist and their interaction must be facilitated. 
Recently, the recovery of the economy and the labour market has been accompanied by clear signs that more institutional importance is being attached to social dialogue. There are also signs of innovation with regard to collective agreements, for example, with the emergence of reconciliation of work and family life, and of gender equality as important domains of negotiation.

We strongly believe that efforts to improve social indicators, leading to closer social convergence towards the EU average, would benefit strongly from more dynamic industrial relations and increasing integration in collective dialogue of both the traditional issues of collective bargaining (wages, working conditions and working time) and reconciliation of work and family life and equal opportunities (as regards gender, but also other dimensions).

\section{NOTES}

1. We use the EU15 average for two reasons: first, for the evolution of some indicators we benefit from longer series of data; second, the EU15 congregates the higher income countries within the EU and so, in convergence terms, comparison with it is perhaps more meaningful.

2. For a more detailed analysis of this process see González and Figueiredo (2015).

3. ISI Growth - Innovation fuelled, sustainable, inclusive growth, accessed 7 December 2017 at http://www. isigrowth.eu/.

4. Eurostat, Annual National Accounts.

5. Eurostat, Income and Living Conditions.

6. Eurostat, [edat_lfse_20].

7. The NEET rates in Portugal show clear divergence as regards the EU28 during the recent crisis: for 20-24-year-olds and in the period 2008-13 it increased from 13.2 to 20.6 per cent in Portugal and from 15.0 to 18.7 per cent in the EU28 (Eurostat, edat_lfse_20).

8. 'STEM' refers to four research and education areas considered to be core domains of knowledge based societies: science, technology, engineering and mathematics.

9. For an analysis of the effects of recent history on the design and the dynamics of the Portuguese welfare state see González and Figueiredo (2015).

10. For a deeper analysis of this process see Távora and González (2016a).

11. For a description of this segmentation and its historical emergence see, among others, Centeno (2013).

12. Conselho Permanente de Concertação Social.

13. The UGT is a union confederation created when union plurality was introduced in Portugal and is generally considered to be open to negotiation and social dialogue. In political terms it is closer to the Socialist Party (centre left) and to the Social Democratic Party (centre right).

14. The CGTP is the oldest union confederation in the country, created as a clandestine organisation before the democratic revolution. It is fairly confrontational and seldom agrees to negotiate and sign social pacts. In political terms it is close to the Communist Party.

15. See also González and Figueiredo (2015) and Távora and González (2016b).

16. The data collected here come from Visser database, which is a standard source for information on industrial relations systems. This dataset is often criticised, however, and other data are often referred to at national level.

17. For an interesting discussion of the issue see Hijzen et al. (2017).

18. Gabinete de Estratégia e Planeamento (Portuguese Ministry of Labour) (GEP/MTSS) (2018), Boletim Estatístico (Statistical Bulletin), January.

19. Conselho Economico e Social (2006, p. 1).

20. For a more detailed analysis of this process see González and Figueiredo (2015).

21. Other changes concerned the continuation of reforms already started in 2003, including the fragility and expiration of collective agreements and decentralisation.

22. Resolution of the Government 90/2012.

23. Governo inviabiliza contratação coletiva, 6 November 2012, accessed 7 December 2017 at http://www.cip. org.pt/irj/servlet/prt/portal/prtroot/com.sap.km.cm.docs/cip/conteudos/areasestrategicas/assuntossociais/ informacao/804d09ab-700a-3010-eca8-c971533a047a.xml.

24. Organisation for Economic Co-operation and Development, Family Database. Data refer to 2014. 
25. This is much truer for childcare than it is for elderly care, which should also be analysed in terms of social convergence.

26. Organisation for Economic Co-operation and Development, Family Database.

27. Conselho Economico e Social (2008, p. 6).

28. PORDATA, European data, accessed 23 November 2017 at http://www.pordata.pt/DB/Europa/Ambien te+de+Consulta/Tabela.

29. For a more detailed analysis see González and Figueiredo (2015).

30. As regards the population aged 25 to 34 (with this same share) Portugal ranks third behind Spain and Malta.

31. Conselho Economico e Social (2001, p. 1).

32. For an important analysis of the benefits of higher education in Portugal, see Figueiredo et al. (2017).

33. According to the OECD database the indicator of strictness of employment protection - collective dismissals (additional provisions) - measures additional costs and procedures involved in dismissing more than one worker at a time (compared with the cost of individual dismissal)'.

34. For a discussion of the historical foundations of the high female activity rate in Portugal see Ruivo et al. (1998).

35. For a discussion on this issue see Távora and Rubery (2013).

36. FESETE, press release, April 2017, accessed at http://fesete.pt/portal/docs/pdf/comacordocalcado2017. pdf.

37. APPICAPS, press release, 19 April 2017, accessed at https://www.apiccaps.pt/news/calcado-fecha-con trato-coletivo-historico/2420.html).

38. For example, see 'Igualdade de género nos salários do calçado', Público, 18 April 2017; 'Mulheres vão ganhar tanto como os homens na indústria do calçado', Jornal de Negócios, 17 April 2017; 'Como a indústria do calçado deu o exemplo', Expresso, 24 April 2017.

39. 'Patrão dos patrões do calçado: "Discussões macias são para mulheres grávidas"', Jornal de Negécios, 18 April 2017.

40. Memorandum of Understanding on Specific Economic Policy Conditionality, Portugal (2011), 17 May, p. 55.

41. 'Annual enterprise statistics by size class for special aggregates of activities (NACE Rev. 2)', available at sbs_sc_sca_r2.

\section{REFERENCES}

Caldas, J.C. (2017), 'Portugal's austerity bail-out', in J.P. Bohoslavsky and K. Raffer (eds), Sovereign Debt Crisis: What We Have Learned, Cambridge: Cambridge University Press, pp. 201-19.

Centeno, M. (2013) O Trabalho, Uma Visão de Mercado. Fundação Francisco Manuel dos Santos, Lisbon: Relógio de agua.

Conselho Economico e Social (CES) (2001), 'Acordo sobre política de emprego, mercado de trabalho, educação e formação', 9 February, Conselho Economico e Social, Comissão Permanente de Concertação Social, Lisbon.

Conselho Economico e Social (CES) (2006), 'Acordo sobre a fixação e evolução da RMMG', 5 December, Conselho Economico e Social, Comissão Permanente de Concertação Social, Lisbon.

Conselho Economico e Social (CES) (2008), 'Acordo tripartido para um Novo Sistema de Regulação das Relações Laborais, das Políticas de Emprego e da Proteção Social em Portugal', 25 June, Conselho Economico e Social, Comissão Permanente de Concertação Social, Lisbon.

Conselho Economico e Social (CES) (2011), 'Acordo Tripartido para a Competitividade e Emprego', 22 March, Conselho Economico e Social, Comissão Permanente de Concertação Social, Lisbon.

Eggertsson, G., J.A. Robbins and E.G. Wold (2018), 'Kaldor and Piketty's facts: the rise of monopoly power in the United States', Washington Center for Equitable Growth working paper, February, accessed 5 November 2017 at http://equitablegrowth.org/working-papers/kald or-piketty-monopoly-power/.

Eichenbaum, M., S. Rebelo and C. Resende (2016), 'The Portuguese Crisis and the IMF', IEO Background Paper, Independent Evaluation Office, IMF, Washington.

Figueiredo, H., M. Portela, C. Sá, J. Cerejeira, A. Almeida and D. Lourenço (2017), 'Benefícios do Ensino Superio'r, Fundação Francisco Manuel dos Santos, Lisbon.

González, P. and A. Figueiredo (2015), 'The European social model in a context of crisis and 
austerity in Portugal', in D. Vaughan-Whitehead (ed.), The European Social Model in Crisis. Is Europe Losing its Soul?, Cheltenham, UK and Northampton, MA, USA: Edgar Elgar and Geneva: ILO, pp. 386-450.

González, P., A. Figueiredo, H. Figueiredo and L.D. Santos (2016), 'Still holding on? Inequality, labour market and middle-income groups in Portugal', in D. Vaughan-Whitehead (ed.), Europe's Disappearing Middle Class? Evidence from the World of Work, Cheltenham, UK and Northampton, MA, USA: Edgar Elgar and Geneva: ILO, pp. 441-94.

González, P., L.D. Santos and M.C. Santos (2009), 'Education and gender wage differentials in Portugal: what can we learn from an age cohort analysis?', Education Economics, 17 (2), 263-78.

Hijzen, A., P. Martins and H. Parlevliet (2017), 'Collective bargaining through the magnifying glass: a comparison between the Netherlands and Portugal', IMF Working Paper No. WP/17/275, November.

Piketty, T. and G. Zucman (2014), 'Capital is back: wealth/income ratios in rich countries 1700-2010', Quarterly Journal of Economics, 129 (3), 1255-310.

Rodrigues, C.F., R. Figueiras and V. Junqueira (2016), 'Desigualdade do Rendimento e Pobreza em Portugal - as consequências sociais do programa de ajustamento', Foundation Francisco Manuel dos Santos, Lisbon.

Ruivo, M., P. González and J. Varejão (1998), 'Why is part-time work so low in Portugal and Spain?', in J. O'Reilly and C. Fagan (eds), Part-time Prospects: An International Comparison of Part-time Work in Europe, North America and the Pacific Rim, London: Routledge, pp. 199-213.

Távora, I. and P. González (2016a), 'The reform of joint regulation and labour market policy during the current crisis: national report on Portugal', in A. Koukiadaki, I. Távora and M. Martínez Lucio (eds), Joint Regulation and Labour Market Policy in Europe during the Crisis, Brussels: ETUI, pp. 321-93.

Távora, I. and P. González (2016b), 'Labour market regulation and collective bargaining in Portugal during the crisis: continuity and change', European Journal of Industrial Relations, $22(3), 251-65$.

Távora, I. and J. Rubery (2013), 'Female employment, labour market institutions and gender culture in Portugal', European Journal of Industrial Relations, 19 (3), 221-37.

Vandenbroucke, F. (2017), 'Comparative social policy analysis in the EU at the brink of a new era', Journal of Comparative Policy Analysis, 19 (4), 390-402. 